\title{
Environmental disclosure and economic efficiency: A correlational evaluation of Spanish ports authorities
}

\author{
Emma Castelló Taliani(iD, Silvia Giralt Escobar(D), Fabricia Silva Da Rosa(iD) \\ Universidad de Alcalá (Spain) \\ emma.castello@uah.es, silvia.giralt@uah.es,_fabriciasrosa@hotmail.com
}

Received November, 2016

Accepted June, 2017

\section{Abstract}

Purpose: Representative correlational study of Spanish Ports Authorities (PA), based on analysis of PA economic efficiency, measured using DEA Data Envelopment Analysis, and PA environmental disclosure. Data employed: environmental reports of 20 PAs examined to gain understanding of Environmental Disclosures; economic management reports of individual ports to obtain the economic variables analyzed. The purpose to identify correlations among variables of environmental disclosure and economic efficiency of port management, with consideration of port overheads and profit focused structure.

Design/methodology: A three-stage study, comprised of: $1^{\text {st }}$ Classification of PAs efficiency; $2^{\text {nd }}$ Analysis of environmental information disclosed, for which an Environmental Disclosure Assessment was defined; 3rd Cluster Analysis to determine correlations of the economic efficiency findings of stage 1 cross-referenced with environmental disclosures of stage 2.

Findings: The results obtained from the study are: classification of all Spanish PAs, although only 20 PAs are analyzed in stages $2^{\text {nd }}$ and $3^{\text {rd }}$; snapshot of 2012 information contained in the Environmental Disclosure Assessment defined, and DEA with results of correlations between the PAs' environmental disclosures and economic efficiency ratings. Among relevant findings, the study shows that Efficient and Marginally Efficient PAs provide best environmental 
disclosures, as defined by type/frequency of reporting and environmental impact management information disclosed. Note: Efficient PAs provide more detailed information on water and energy management.

Research limitations/implications: 8 PAs not supplying environmental reports were excluded from stages 2-3, due to which final results do not include $100 \%$ of PAs of the Spanish port system.

Originality/value: The analysis allows to identify correlations among variables of environmental disclosure and economic efficiency of port management in Spanish Ports Authorities.

Keywords: Environmental Disclosure, Economic Efficiency, DEA (Data Envelopment Analysis), Ports

Jel Codes: C61, L92, M41

\section{Introduction}

Spanish Law 33/2010 (enacted 7 August 2010), contains a key aspect of the new legal framework regulating ports: the environmental components of port activity, which includes infrastructures, installations/facilities and services, all with potentially significant environmental impacts. The law considers environmental protection a responsibility of ports, and advocates the introduction of environmental management and sustainability mechanisms in Port Authority management.

In this regard, it should be noted that Port Authorities (hereinafter PAs) follow management models similar to those of private companies, designed to maximize income and optimize profits. Spanish Ports compete among themselves, and with other freight logistics and transport models for business, due to which achieving maximum economic efficiency is fundamental.

This paper proposes a dual perspective: economic efficiency, and environmental disclosure, an evaluation of port environmental management as it correlates to environmental reporting and economic results. The objective is to characterize PAs taking into account the two. The reference data for the study, taken from 2012, two years after enactment of Law 33/2010, provides insight on how PA Environmental Management Accounting and Reporting systems have responded since enactment of the law. 
Numerous Environmental Accounting studies conducted in Spain (OECD, 2015; da Rosa, Lunkes, Pfitscher, Feliu \& Soler, 2012) and abroad (Tanc \& Gokoglan, 2015; KMPG, 2015; Burritt, 2012; Negash, 2012; Burnett \& Hansen, 2008; Berthelot, Cormier \& Magnan, 2003) document rising interest by companies in providing stakeholders with facts and figures on their environmental performance through the publication of annual sustainability reports.

Taking as reference the three main areas of research noted by da Rosa et al. (2012, pp. 29) in an exhaustive review of national and international literature on Environmental Accounting: Environmental Indicators, Environmental Disclosure or ED, and Fundamentals of Environmental Accounting, this study analyzes the correlations of environmental disclosure of PAs, with environmental performance, and economic performance.

Environmental indicators play an important role in the assessment and monitoring of environmental measures impacts. (Cerreta \& Toro, 2012).

Among the many port-specific studies examining the subject are those of (Whitlam, 2013; Synnot, 2013; Giner, da Rosa, Lunkes, Ripoll \& Crespo, 2012), on design of an Environmental Management System (EMS) for ports (U.S. EPA 2007), on improved port services quality through environmental regulation ((Bahauddin, 2014; Luttenberger, 2010), on cost-opportunity study of environmental regulation of PAs (Yang, 2013; Stojanovic, Smith \& Wooldridge, 2006) on the impact of regulation on port management. The environmental efficiency of ports depends, to a great extent, on the environmental management of port concessionaires and other service providers, conducting activity within the port area. While Port Authorities do not have "legal" authority to sanction non-compliance by these actors intervening in Port functions, they do have the power to act via inclusion of environmental compliance requirements in tender specifications, operational guidelines, regulations, economic incentives, and supervision fees, among others (Puertos del Estado, 2012, pp. 66-67). 


\section{Research}

As noted by Burnett and Hansen (2008, pp. 552), studies on Environmental Disclosure (hereinafter ED) have explored aspects such as: characteristics of the reporting entities, type of information reported, and the reasons that organizations opt to voluntarily disclose their environmental performance data. Researchers have also conducted comparative studies of the relationships (two by two) between: Environmental disclosure, environmental performance and economic performance.

The number of studies analyzing the relationships between environmental performance and the financial and economic performance of companies has also risen. Molina-Azorín, Claver-Cortés, López-Gamero and Tarí (2009), maintain that good environmental management generally has a positive impact on the financial performance of companies, and vice versa, referencing the previously mentioned quantitative studies of activity sectors, countries and settings (Ferrón, de la Torre \& Aragón, 2010).

From an economic perspective, several studies have confirmed the importance of incorporating environmental aspects in port management, (sedimentation in aquatic environments, air emissions, waste generation, energy and water consumption and noise, among others), to guarantee better economic performance, affirming that improved environmental performance can reduce costs and enhance stakeholder engagement, with the ensuing positive economic results for the company (Poltrack, 2000; Kolk \& Veen, 2002; Hou \& Gerrlings, 2016).

As concluded by Al-Tuwaijri, Christensen and Hughes (2004), good environmental performance is associated, to a significant degree, with good economic performance, and also with more complete environmental disclosure and reporting. Thus, our research involved a descriptive, cross-cutting, 3-stage study of the year 2012, using Data Envelopment Analysis, to obtain a snapshot of the correlations between environmental disclosure by Ports Authorities and their economic efficiency.

A review of the literature on the efficiency of maritime ports shows that Stochastic Frontier Analysis (SFA) and Data Envelopment Analysis (DEA) are the quantitative techniques most frequently employed.

In this regard, we remit to the full review of the literature conducted by SchØyen and Odeck (2013, pp. 199-202), which documented that of 47 articles on port efficiency written between 1993 and 2008, 36 used DEA and 11 SFA, which, in the authors' opinion shows that DEA Data Envelopment Analysis is the tool most frequently used, particularly in the most recent studies (Horgn-Jinh \& Ling-Chu, 2012; Navarro \& Zamora, 2014). 
DEA arose as a welcome solution to a difficult need: calculating economic product cross-referenced with efficiency. DEA analyzes inputs and outputs and determines the relative efficiency of DMUs (Decision Making Unit: companies, strategic business units, processes and activities, among others) performing similar activities. In our study, the DMUs are the Ports Authorities of the Spanish Port System.

In the first stage of the study, a DEA analysis was done of all 28 Spanish Ports Authorities (46 ports managed), thereby ensuring that sample and evaluations of economic efficiency covered all members of the Spanish port system. The 20 PAs that had issued environmental reports were included in the second and third stages of the study.

We opted for a DEA efficiency analysis with variable returns to scale (Banker, Charnes and Cooper (BCC) model). In this model, the underlying hypothesis is that any variation of input to a DMU leads to a -not necessarily proportional- change in outcome. In other words, changes in scale affect efficiency. The model calculates the relative efficiency of each PA, including changes in operational scale, to reflect the current reality of the PA comprising the Spanish Ports System.

The study performed was designed based on maximum outputs, an essential efficiency factor. The potential for actions on the expense structure of PAs is constrained, due to the nature of activity, as most PA overhead expenses are fixed.

The data used in this analysis were obtained from the official periodical reports issued by the AssistantDirectorate of Management Analysis of the Public Entity Puertos del Estado.

\subsection{Characteristics of the sample and variables used in the study}

The DEA economic efficiency analysis was done for the entire population, the 28 PAs who represent the 46 Spanish ports of general interest. However, as mentioned earlier, in the environmental analysis the final sample is comprised only of the 20 PAs that publish environmental reports. Focusing the study in this way, over various stages, allowed us to determine a priori, the economic efficiency profile of the PAs not considered in the second stage of the study.

In the first stage of the study, an Economic Efficiency analysis was performed, with variables described as inputs and outputs. The variables applied in the DEA analysis are:

- Inputs

- Depreciation and amortization of non-current assets 


\section{- Personnel Expenses \\ $\circ$ Other operating expenses}

- Outputs

\section{- Operating Revenue}

Table 1 shows the summary of the basic statistics of these variables for the period analysed (in euros).

\begin{tabular}{|l|c|r|r|r|}
\cline { 2 - 5 } \multicolumn{1}{c|}{} & $\begin{array}{c}\text { Operating } \\
\text { Revenue }\end{array}$ & $\begin{array}{c}\text { Personnel } \\
\text { Expenses }\end{array}$ & Amortization & $\begin{array}{c}\text { Other operating } \\
\text { expenses }\end{array}$ \\
\hline Average & $43,073,678.57$ & $8,381,642.86$ & $13,540,571.43$ & $11,413,357.14$ \\
\hline $\max$ & $169,918,000.00$ & $31,239,000.00$ & $45,951,000.00$ & $42,197,000.00$ \\
\hline $\min$ & $7,417,000.00$ & $2,779,000.00$ & $2,547,000.00$ & $1,113,000.00$ \\
\hline S.D. & $39,031,428.39$ & $5,910,328.72$ & $11,312,381.65$ & $10,223,583.63$ \\
\hline
\end{tabular}

Table 1. Basics statistics - Inputs/Outputs

For the second stage of the study, analysis of the environmental information disclosed by the PAs, an Environmental Disclosure Assessment was designed. The variables are detailed in Tables 2 and 3. The study included variables taken from the first stage of the study, that with DEA served to classify PAs in the following categories: efficient (score 100\%), marginally efficient ( $\geq 90 \%$ ), marginally inefficient $(\geq 80 \%)$ and inefficient $(<80 \%)$. 


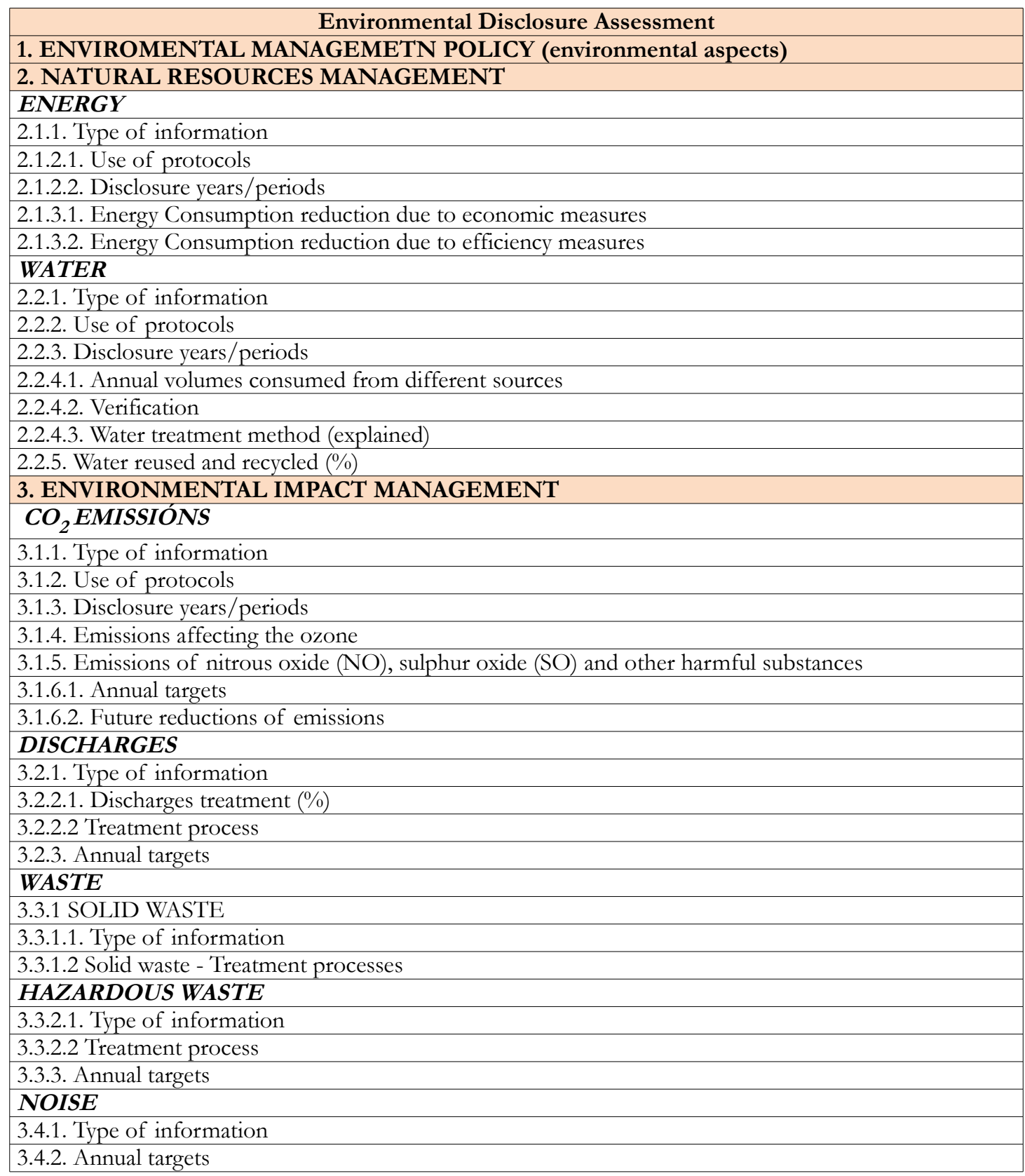

Table 2. Environmental Disclosure Assessment 


\begin{tabular}{|c|c|}
\hline Definition & Scale/items \\
\hline 1. Environmental Aspects in PAs reporting & $\begin{array}{l}\text { - } \text { none } \\
\text { - } 1 \text { aspect } \\
\text { - } 2 \text { aspects } \\
\text { - } 3 \text { aspects } \\
\text { - } 4 \text { aspects } \\
\text { - } 5 \text { aspects } \\
\text { - } 6 \text { aspects } \\
\text { - } 7 \text { aspects } \\
\text { - } 8 \text { aspects } \\
\text { - } 9 \text { aspects }\end{array}$ \\
\hline $\begin{array}{l}\text { 2.1.1. Energy- Type of information } \\
\text { 2.2.1. Water - Type of information } \\
\text { 3.1.1. } \mathrm{CO}_{2} \text { emissions - Type of information } \\
\text { 3.2.1. Discharges- Type of information } \\
\text { 3.3.1.1. Solid waste -Type of information } \\
\text { 3.3.2.1. Hazardous waste -Type of information } \\
\text { 3.4.1. Noise -Type of information }\end{array}$ & $\begin{array}{l}\text { - No information } \\
\text { - Descriptive } \\
\text { - Monetary } \\
\text { - Quantitative } \\
\text { - Descriptive \& Monetary } \\
\text { - Descriptive \& Quantitative } \\
\text { - Monetary \& Quantitative } \\
\text { - Descriptive, Monetary \& Quantitative }\end{array}$ \\
\hline $\begin{array}{l}\text { 2.1.2.1. Energy protocols } \\
\text { 2.2.2. Water protocols } \\
\text { 2.2.4.1. Annual volumes consumed from different sources } \\
\text { 2.2.4.2. Water Verification } \\
\text { 2.2.4.3. Water treatment method (explained) } \\
\text { 3.1.2. } \mathrm{CO}_{2} \text { emissions protocols } \\
\text { 3.1.4. Emissions affecting the ozone } \\
\text { 3.1.5.Emissions of nitrous oxide (NO), sulphur oxide } \\
\text { (SO) and other harmful substances } \\
\text { 3.2.2.2 Discharges -Treatment processes } \\
\text { 3.3.1.2 Solid waste - Treatment processes } \\
\text { 3.3.2.2 Hazardous waste - Treatment processes }\end{array}$ & $\begin{array}{l}\text { - } \mathrm{No} \\
\text { - Yes }\end{array}$ \\
\hline $\begin{array}{l}\text { 2.1.2.2. Energy- Disclosure year/periods } \\
\text { 2.2.3. Water- Disclosure year/periods } \\
\text { 3.1.3. } \mathrm{CO}_{2} \text { emissions - Disclosure year/periods }\end{array}$ & $\begin{array}{l}\text { - No data } \\
\text { - Generic } \\
\text { - Without specific period of time } \\
\text { - Annual historical data } \\
\text { - Data for periods of less than one year } \\
\text { - } 3 \text { years of historical data } \\
\end{array}$ \\
\hline $\begin{array}{l}\text { 2.1.3.1. Energy Consumption reduction due to economic } \\
\text { measures } \\
\text { 2.1.3.2 Energy Consumption reduction due to energy } \\
\text { efficiency measures } \\
\text { 2.2.5. Water reused and recycled }(\%) \\
\text { 3.1.6.1. Emissions reduction annual targets } \\
\text { 3.1.6.2. Future reductions of emissions } \\
\text { 3.2.2.1. Discharges treatment }(\%) \\
\text { 3.2.3. Discharges -annual target } \\
\text { 3.3.3. Hazardous waste - reduction target } \\
\text { 3.4.2. Noise- annual target }\end{array}$ & $\begin{array}{l}\text { - } 0 \% \\
\text { - } 25 \% \text { or less } \\
\text { - } 50 \% \text { or less } \\
\text { - } 75 \% \text { or less } \\
\text { - More than } 75 \%\end{array}$ \\
\hline Economic DEA Score & $\begin{array}{l}\text { Efficient } \\
\text { Marginally efficient } \\
\text { Marginally inefficient } \\
\text { Inefficient }\end{array}$ \\
\hline
\end{tabular}

Table 3. Variables contained in the analysis and scales applied 


\section{Results}

\subsection{Results of the first stage}

The use of DEA analysis with variable returns to scale to maximize the outputs considered, gives as a result the classification of the efficiency assigned to the different units analysed, to which a value of $0 \%-100 \%$ is assigned, and, thus the score assigned to efficient and inefficient PAs.

\begin{tabular}{|l|r|}
\hline Unit & Score \\
\hline A CORUÑ & $\mathbf{9 2 , 0 7}$ \\
\hline ALICANTE & 70,49 \\
\hline ALMERÍA & 64,41 \\
\hline AVILÉS & $\mathbf{8 6 , 6 2}$ \\
\hline BAHÍA DE ALGECIRAS & 100 \\
\hline BAHIA DE CADIZ & 70,09 \\
\hline BALEARES & $\mathbf{9 4 , 8 3}$ \\
\hline BARCELONA & 100 \\
\hline BILBAO & $\mathbf{7 4 , 3 5}$ \\
\hline CARTAGENA & 100 \\
\hline CASTELLÓN & 69,26 \\
\hline CEUTA & 100 \\
\hline FERROL-SAN CIBRAO & $\mathbf{8 4 , 7 6}$ \\
\hline GIJÓN & $\mathbf{8 8 , 3 5}$ \\
\hline HUELVA & $\mathbf{8 2 , 2 8}$ \\
\hline LAS PALMAS & $\mathbf{9 0 , 7 7}$ \\
\hline MÁLAGA & 61,96 \\
\hline MARÍN Y RÍA DE PONTEV. & 100 \\
\hline MELILLA & $\mathbf{7 6 , 2 2}$ \\
\hline MOTRIL & 100 \\
\hline PASAJES & 98,98 \\
\hline S.CRUZ DE TENERIFE & $\mathbf{7 8 , 3 5}$ \\
\hline SANTANDER & $\mathbf{5 4 , 7 7}$ \\
\hline SEVILLA & 84,65 \\
\hline TARRAGONA & $\mathbf{8 5 , 2}$ \\
\hline VALENCIA & 100 \\
\hline VIGO & 62,84 \\
\hline VILAGARCÍA & 100 \\
\hline
\end{tabular}

Table 4. DEA Scores - Economic Efficiency (2012)

The assumptions applied in DEA analysis, were: scores below $100 \%$ indicate relative level of inefficiency, inputs and outputs, with reference to the economic performance of the PA of the Spanish port system.

As noted earlier, the absolute score, reflected in Table 4, was divided among four categories: efficient PAs (score 100\%), marginally efficient PAs ( $\geq 90 \%)$, marginally inefficient PAs $(\geq 80 \%)$ and inefficient PAs $(<80 \%)$. In Table 4, the PAs not included in the environmental disclosure analysis are marked in red.The scores received in the first stage by the 8 PAs excluded from the second stage of the study 
were: 2 efficient PAs (score 2), 1 marginally efficient PAs $(\geq 1), 1$ marginally inefficient PAs $(\geq 1) 4$ and inefficient PAs (<4). Thus, the overall study refers to a sample representing $71.42 \%$ of the total population of Spanish PAs, and maintains its relevance.

Regarding the scores and categorization of the 20 PAs included in the stage 2: 30\% are efficient, 15\% marginally efficient, 25\% marginally inefficient and 30\% inefficient (Table 5).

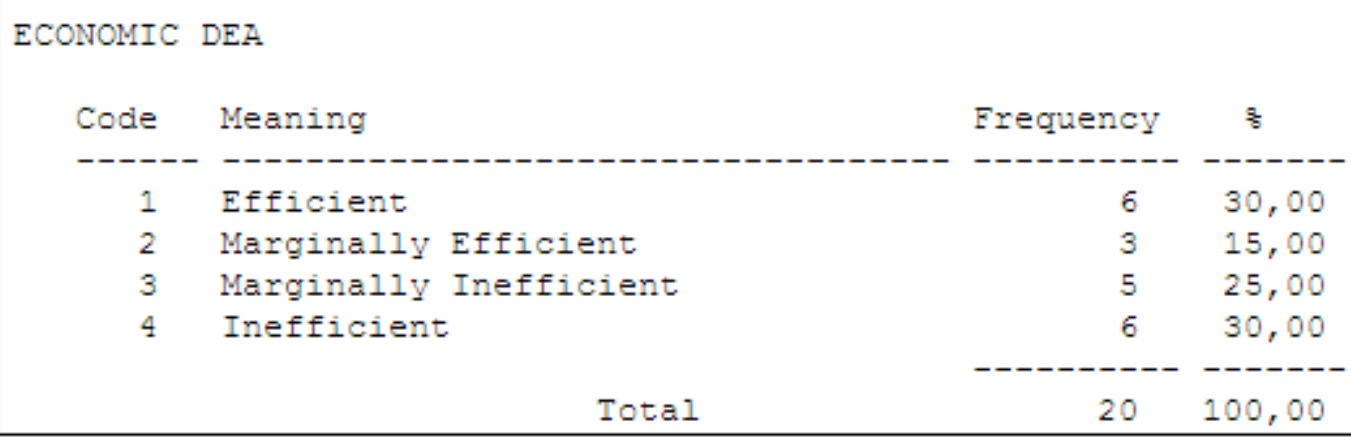

Table 5. PA classification by DEA Scores

\subsection{Results of the second stage of the study}

Of the PAs examined in the second stage (those providing environmental reports and environmental disclosures) $85 \%$ included 5 or more environmental aspects in their reporting (Figure 1). The top 4 categories for which PAs provided descriptive and quantitative reporting (by percentage of PAs reporting on item) were: energy (50\%); water and discharges (65\%); solid and hazardous waste (75\%); and $85 \%$ reported $\mathrm{CO}_{2}$ emissions (Table 6$)$.

In the reports examined, up to three years of historical data (the maximum breakdown) was supplied by PAs on the following items: $\mathrm{CO}_{2}$ emissions (40\% of PAs), water and energy, 50\% and 55\%, respectively (see Table 7).

Of these, all included information on energy management and $\mathrm{CO}_{2}$ emissions protocols, with $85 \%$ reporting on water use protocols.

Regarding energy: none of the PAs in this category provided numbers (percentages of savings) on lower energy consumption, although $65 \%$ reported reductions of up to $25 \%$ due to energy efficiency measures. 
$85 \%$ of PAs reported on annual water volumes consumed from different sources; $70 \%$ of these Authorities have certified verification issued by independent experts. Regarding water treatment methods, while $95 \%$ of PAs explain the method used, only 35\% supply data on the percentages of reused and recycled water (Table 8).

In the specific case of emissions, all PAs reported emissions affecting the ozone, emissions of nitrous oxide (NO), sulphur oxide (SO) and other harmful substances. $50 \%$ of the PAs cite annual emissions reduction targets of up $25 \%$, and one PA has a $50 \%$ target.

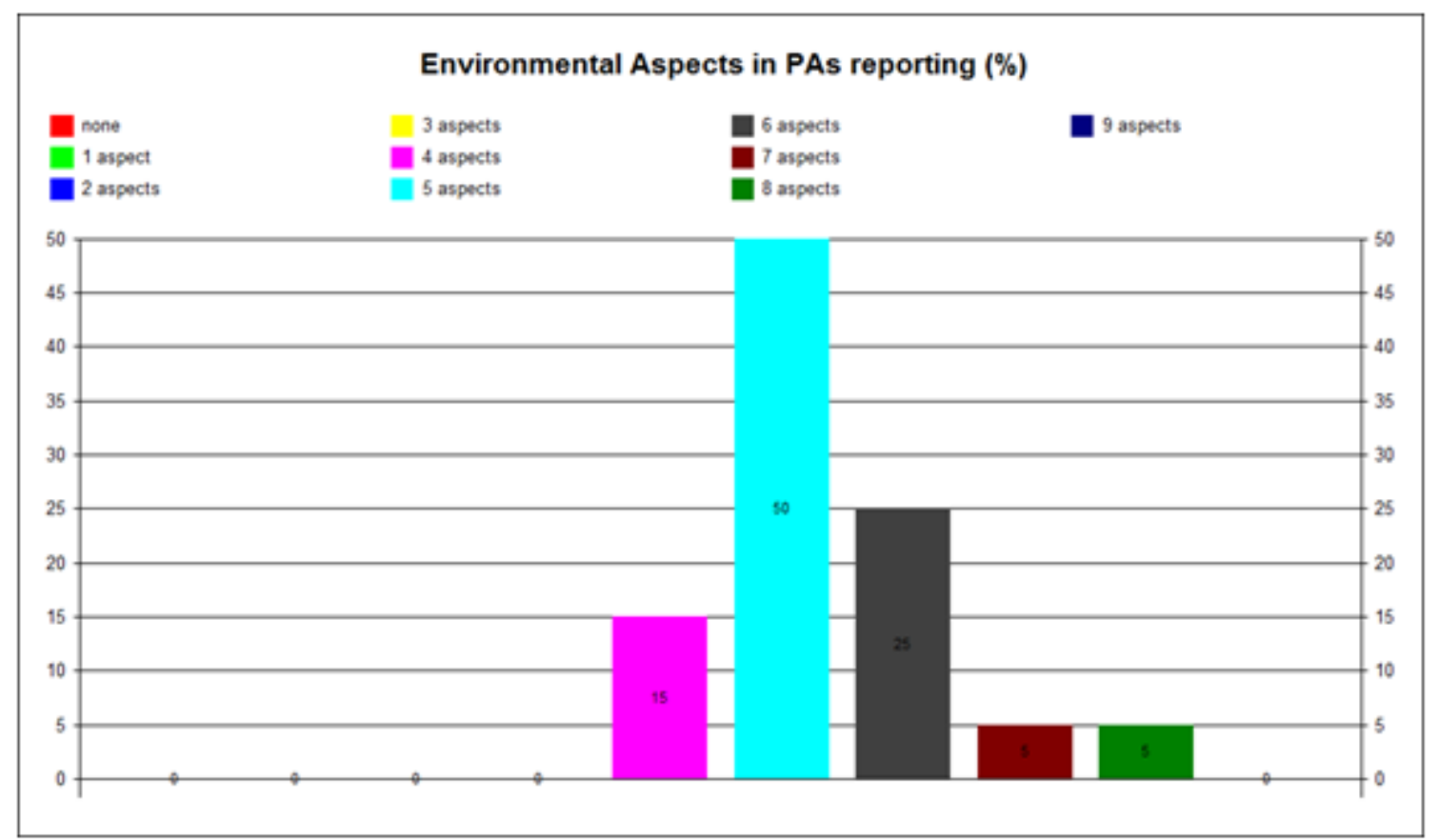

Figure 1. Environmental Management Policy

All of the PAs explain treatment processes for discharges, solid and hazardous wastes.65\% of PAs report the percentage of discharges treated, although 50\% set no future reduction or treatment targets (breakdown in Table 9). Regarding future reduction targets, $45 \%$ set no hazardous waste reduction target, and 75\% no noise reduction target (Table 10). 
2.1.1. ENERGY Type of information

$\begin{array}{rrrr}\text { Code Meaning } & \text { Frequency } & \text { \% } \\ 4 & \text { Quantitative } & 3 & 15,00 \\ 5 & \text { Descriptive \& Monetary } & 1 & 5,00 \\ 6 & \text { Descriptive \& Quantitative } & 10 & 50,00 \\ 7 & \text { Monetary \& Quantitative } & 2 & 10,00 \\ 8 & \text { Descriptive, Monetary \& Quantitative } & 4 & 20,00 \\ & \text { Total } & -100\end{array}$

2.2.1. Water Type of information

\begin{tabular}{|c|c|c|c|}
\hline Code & Meaning & Frequency & s \\
\hline & 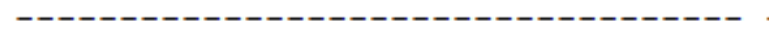 & ----- & -- \\
\hline 2 & Descriptive & 2 & 10,00 \\
\hline 5 & Descriptive \& Monetary & 1 & 5,00 \\
\hline 6 & Descriptive \& Quantitative & 13 & 65,00 \\
\hline 7 & Monetary \& Quantitative & 1 & 5,00 \\
\hline 8 & Descriptive, Monetary \& Quantitative & 3 & 15,00 \\
\hline
\end{tabular}

Total

20100,00

3.1.1. CO2 Emissions Type of Information

\begin{tabular}{|c|c|c|c|}
\hline Code & Meaning & Frequency & 홍 \\
\hline----- & 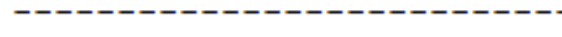 & --------- & ----- \\
\hline 2 & Descriptive & 1 & 5,00 \\
\hline 5 & Descriptive \& Monetary & 1 & 5,00 \\
\hline 6 & Descriptive \& Quantitative & 17 & 85,00 \\
\hline 7 & Monetary \& Quantitative & 1 & 5,00 \\
\hline & Total & 20 & 100,00 \\
\hline
\end{tabular}

3.2.1. DISCHARGES Type of information

$\begin{array}{clrr}\text { Code Meaning } & \text { Frequency } & \text { \% } \\ - & \text { Descriptive } & 2 & 10,00 \\ 5 & \text { Descriptive \& Monetary } & 1 & 5,00 \\ 6 & \text { Descriptive \& Quantitative } & 13 & 65,00 \\ 7 & \text { Monetary \& Quantitative } & 2 & 10,00 \\ 8 & \text { Descriptive, Monetary \& Quantitative } & 2 & 10,00 \\ & \text { Total } & -100\end{array}$




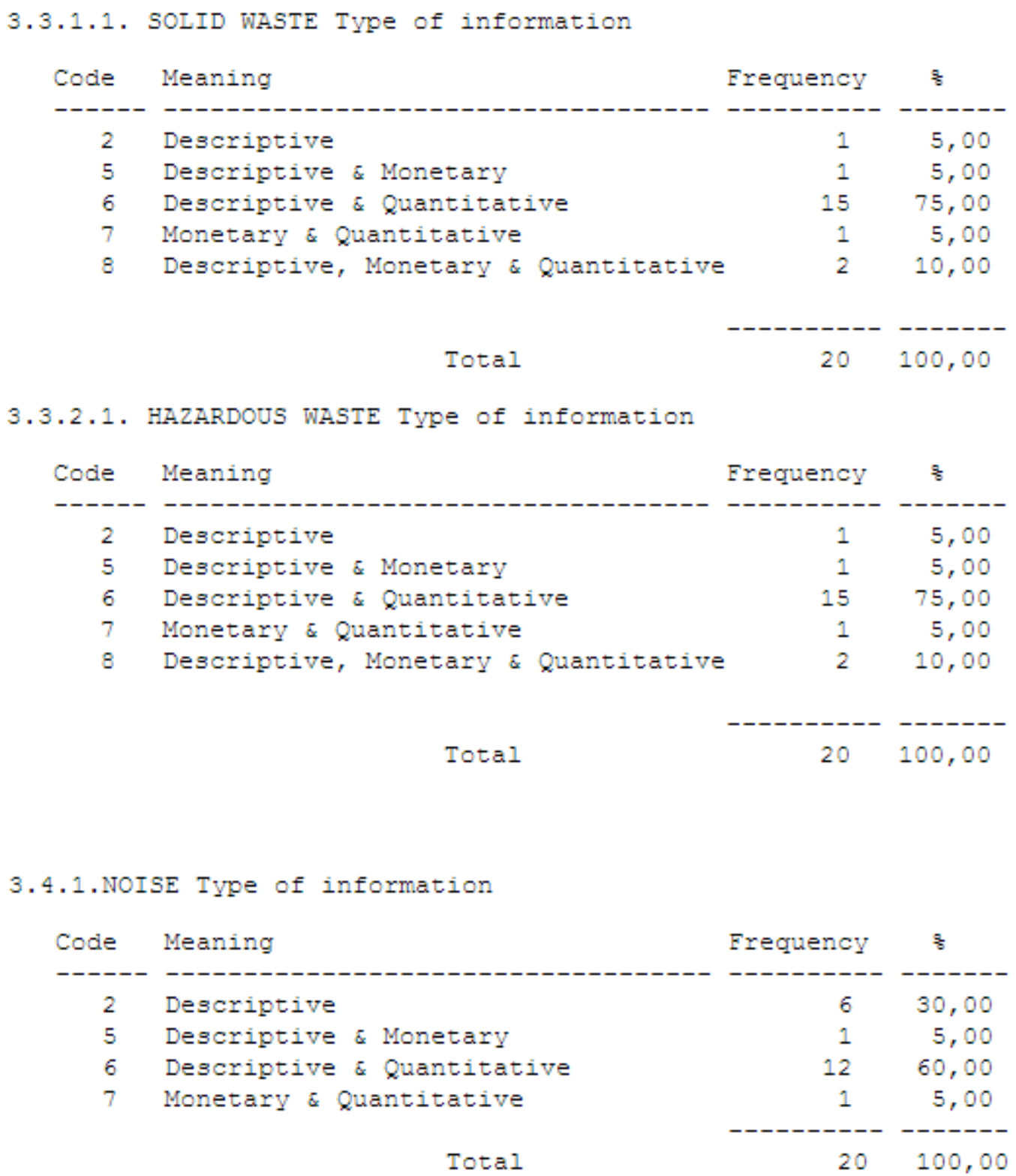

Table 6. Type of environmental information disclosed 


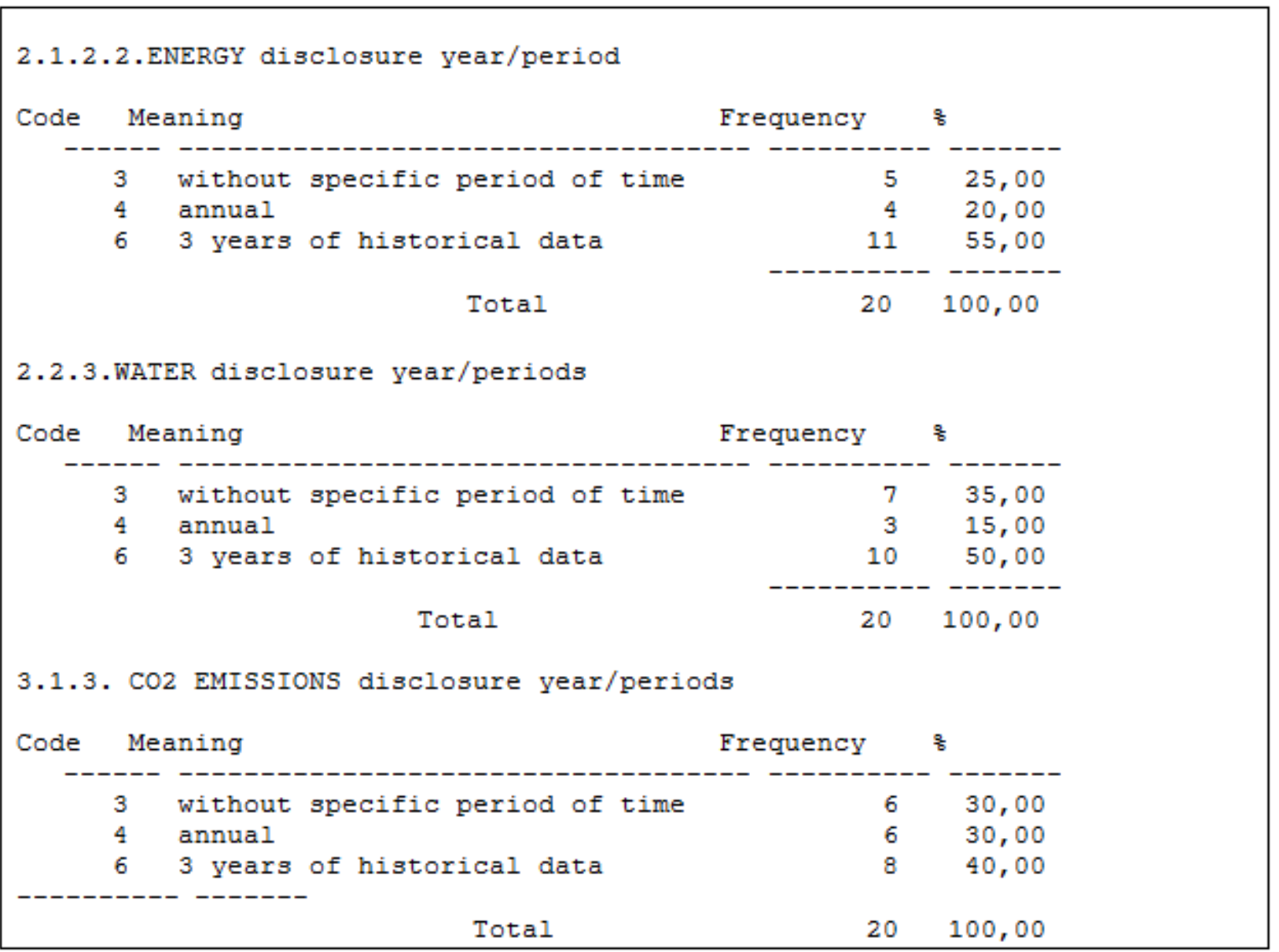

Table 7. Frequency of environmental information disclosed

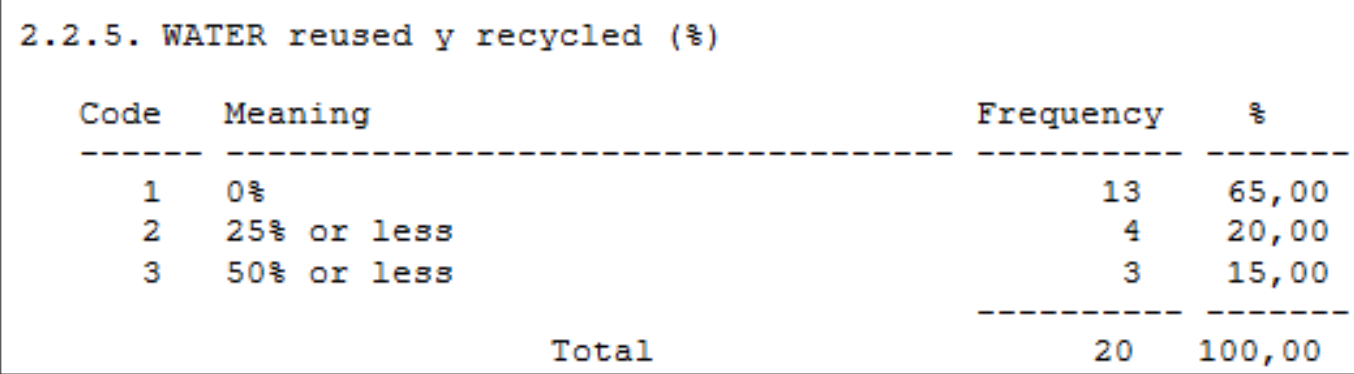

Table 8. Percentages of reused and recycled water 


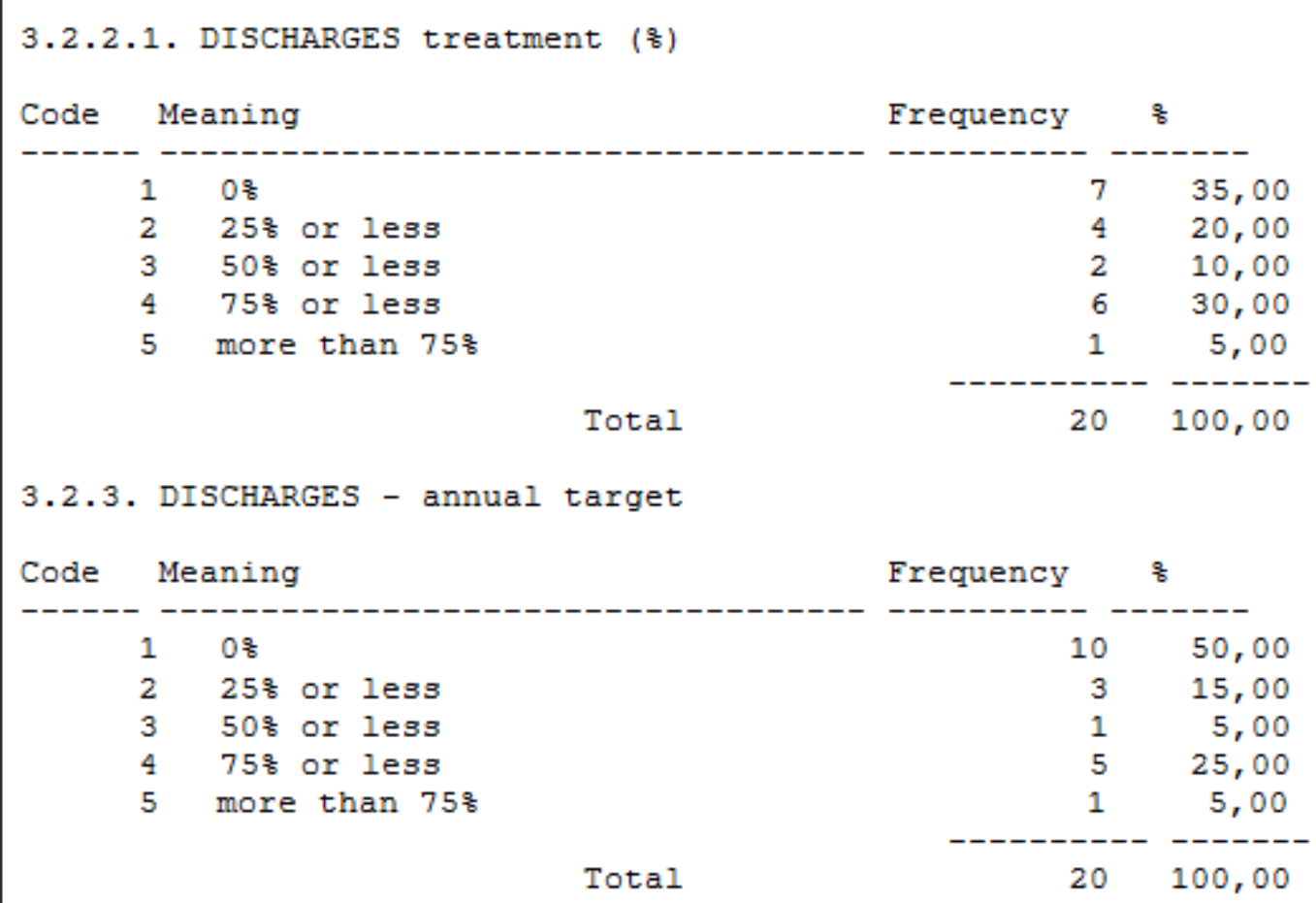

Table 9. Discharges Management

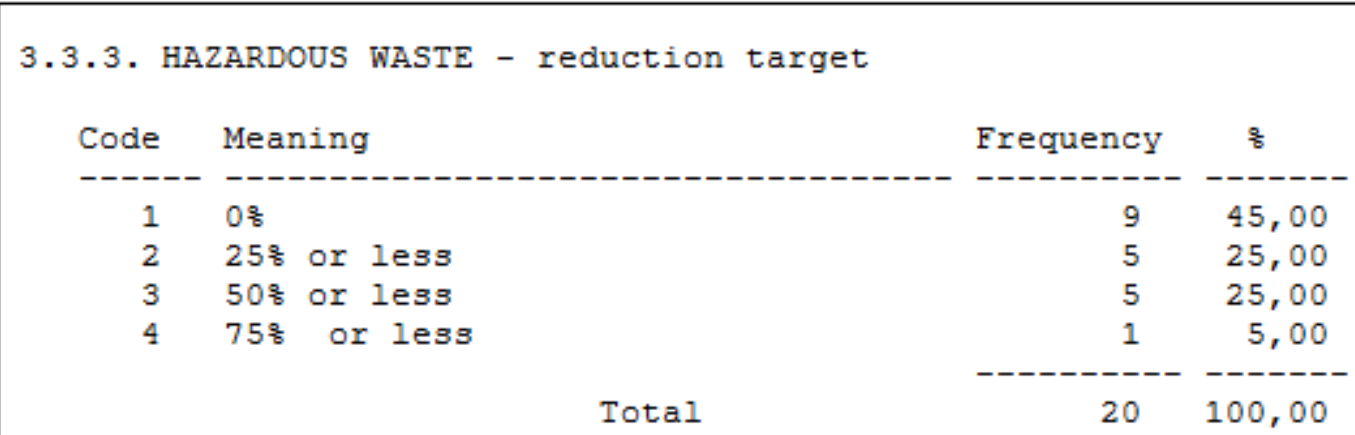

3.4.2. NOISE - annual target

\begin{tabular}{|c|c|c|c|}
\hline Code & Meaning & Frequency & $z$ \\
\hline & 0 용 & 15 & 75,00 \\
\hline & 25 옹 or less & 2 & 10,00 \\
\hline & $75 \%$ or less & 1 & 5,00 \\
\hline & more than $75 \%$ & 2 & 10,00 \\
\hline & & 20 & 100,00 \\
\hline
\end{tabular}

Table 10. Hazardous and Noise - reduction targets 


\subsection{Results of the third stage of the study}

The third stage of the study involved a correlational analysis of the results of the economic efficiencies found in the first stage, and analysis of the PAs environmental disclosure reporting in the second stage. The objective was to characterize the efficiency groups found in the first stage, and compare it with the environmental disclosure information reported by PAs.

4 cluster analyses were performed. Group or cluster analysis techniques are statistical techniques serving to identify groups that, while otherwise different, are internally homogenous. We used the Johnson algorithm, full chainbuild-up, for all cluster analyzes, in which distance between two clusters (groups) is taken as the greatest between the elements integrating those groups. (Santesmases, 2005, pp. 388).

The variables used in these analyses, and profile obtained for each of the groups is shown below.

\subsubsection{PA groups: From analysis of type of environmental information disclosed}

The variables considered in the first cluster analysis, done to classify PAs based on type of environmental information disclosed, and their economic efficiency rating in the first stage of the study were:

- 2.1.1. ENERGY Type of information

- 2.2.1. WATER Type of information

- 3.1.1. $\mathrm{CO}_{2}$ EMISSIONS Type of information

- 3.2.1. DISCHARGES Type of information

- 3.3.1.1. SOLID WASTE Type of information

- 3.4.1. NOISE Type of information

- DEA Economic efficiency score

Table 11 contains the dendrogram obtained from this analysis, reflecting the classification obtained of the PAs. 


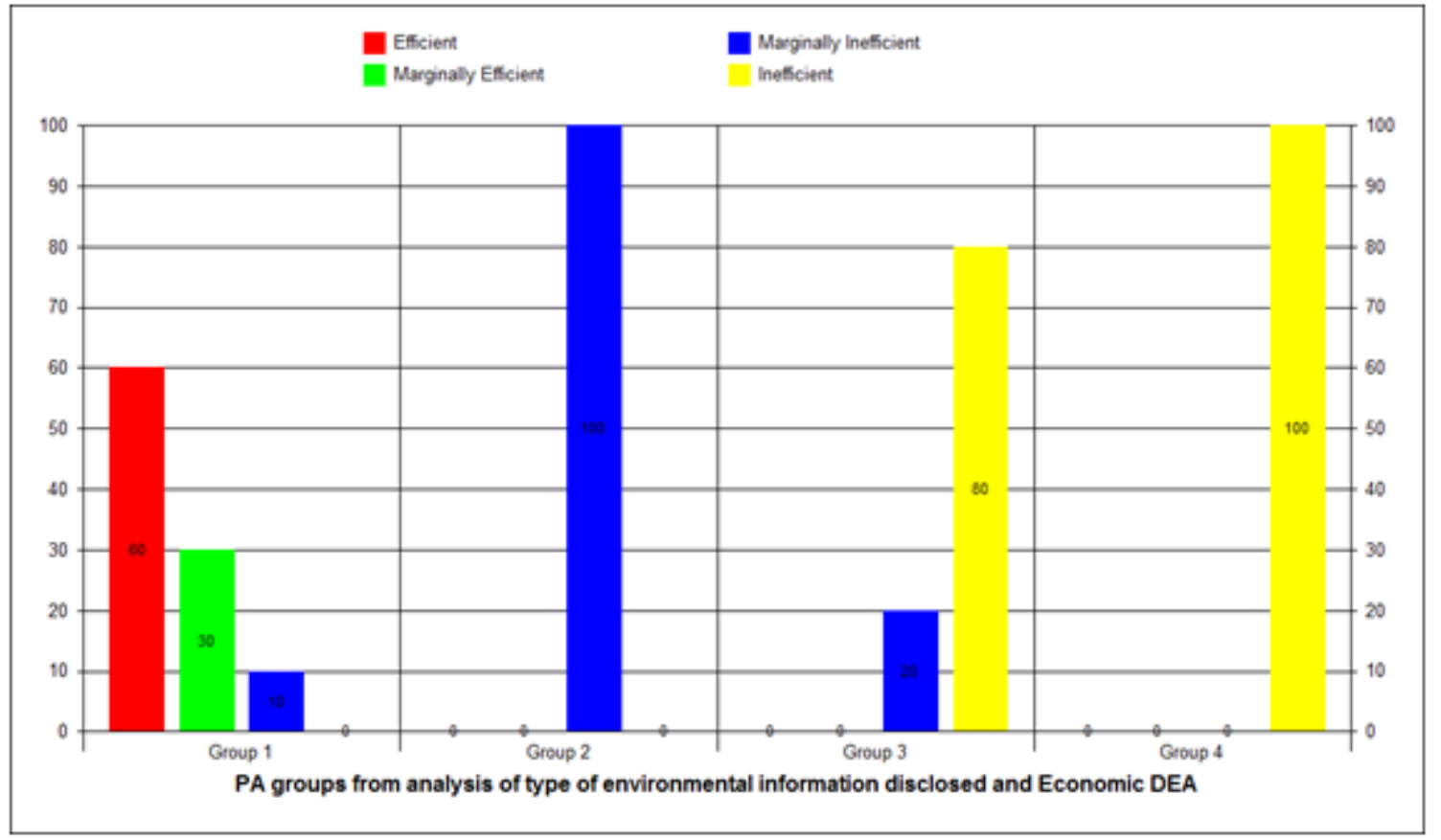

Figure 2. Efficiency distribution by group

Figure 2 shows efficiency distribution by group as determined via cross-tabulation of the previously defined efficiency categories and groups obtained in the first cluster analysis.

As shown in the figure, group 1 is the largest. It includes all PAs ranked as efficient (Bahía de Algeciras, Barcelona, Cartagena, Ceuta, Motril and Valencia); all ranked as marginally efficient (A Coruña, Las Palmas and Balearic Islands), and one PA (Gijón) ranked as marginally inefficient, which obtained the highest efficiency score $(88.35 \%)$ among the marginally efficient PAs, placing it near the cut-off for the marginally efficient category. Group 2 is comprised of the marginally inefficient PAs with efficiency scores above 84\% (Avilés, Ferrol and Tarragona). Group 3 includes four inefficient PAs with efficiency scores above 62\% (Bilbao, Castellón, S. Cruz de Tenerife and Melilla) and one marginally inefficient PA (Huelva) that received the lowest efficiency score of its category. Group 4 includes the 2 PAs (Santander and Vigo), with the lowest economic efficiency scores, due to which both were ranked as inefficient. 


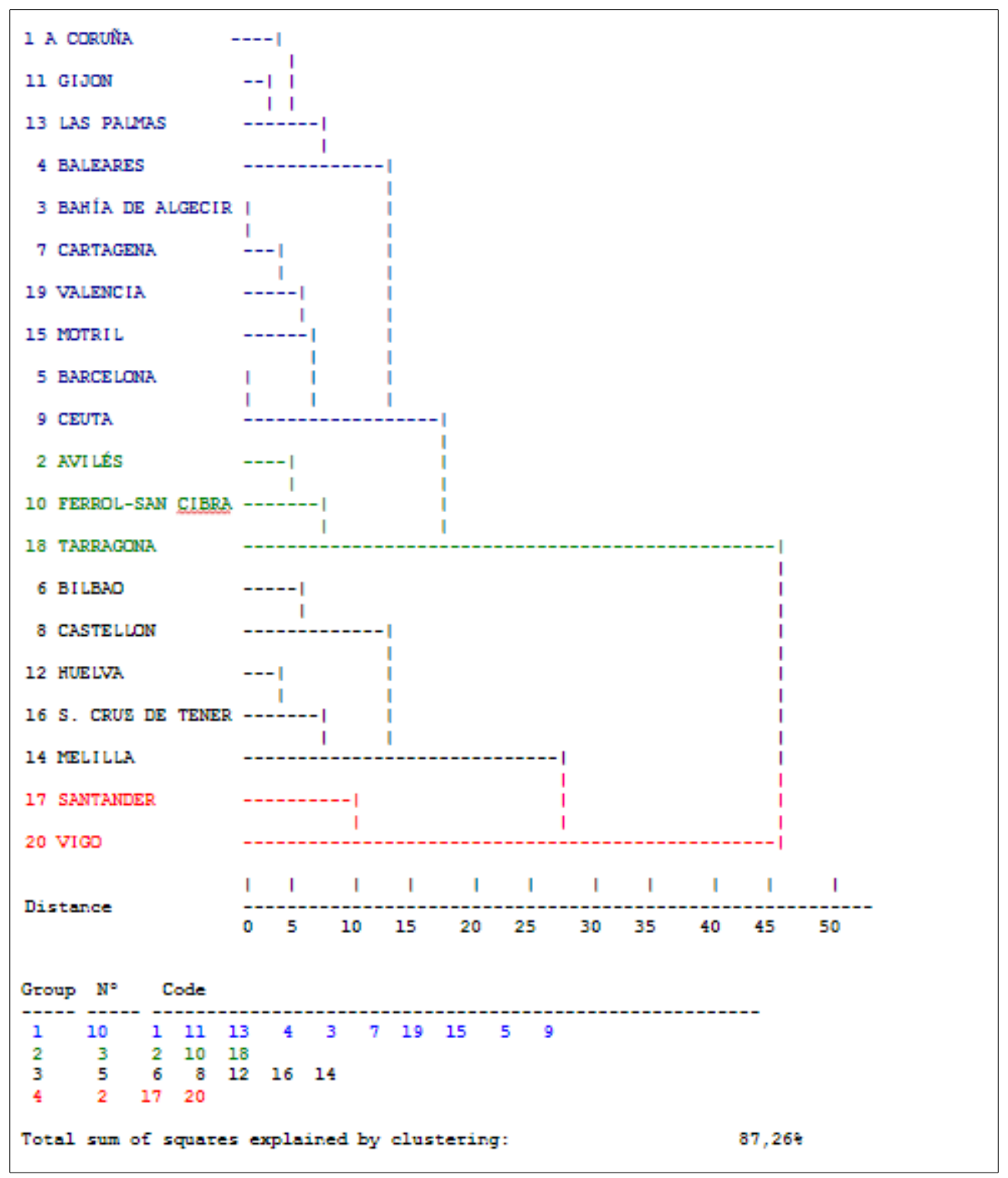

Table 11. Dendrogram-PAs classification based on type of environmental information disclosed

In each of the groups, the variables showing significant average value differences are those related to the type of environmental information disclosed on water (variable 2.2.1), discharges (variable 3.2.1) and noise (3.4.1.).

Table 12 shows the cross-tabulation of the values of those variables, and the groups obtained. Thus, the group providing best quality information disclosure on water, discharges and noise is group 1, which includes all efficient and marginally efficient PAs. The group providing the poorest breakdown of environmental disclosure is group 2, which includes the majority of the marginally inefficient PAs. For the 3 variables mentioned above, it should be noted that groups 3 and 4 , the inefficient PAs, provide a better breakdown in their disclosures than does group 2. 
Rows: 2.2.1. Water Type of information

Columa: PA groups from analysis of type of environmental information disclosed and Economic DEA

\begin{tabular}{|c|c|c|c|c|c|c|c|c|c|c|}
\hline \multirow[b]{2}{*}{ 2.2.1. Water } & \multicolumn{2}{|c|}{ TOTAL } & \multicolumn{2}{|c|}{ Group 1} & \multicolumn{2}{|c|}{ Group 2} & \multicolumn{2}{|c|}{ Group 3} & \multicolumn{2}{|c|}{ Group 4} \\
\hline & Frec & 8 & Frec & 8 & Frec & 8 & Frec & 8 & Frec & \& \\
\hline 2 Descriptive & 2 & 10,00 & 0 & 0,00 & 2 & 66,67 & 0 & 0,00 & 0 & 0,00 \\
\hline $\begin{array}{l}5 \text { Descriptive } 8 \\
\text { Monetary }\end{array}$ & 1 & 5,00 & 0 & 0,00 & 0 & 0,00 & 1 & 20,00 & 0 & 0,00 \\
\hline $\begin{array}{l}6 \text { Descriptive } \alpha \\
\text { Quantitative }\end{array}$ & 13 & 65,00 & 8 & 80,00 & 1 & 33,33 & 3 & 60,00 & 1 & 50,00 \\
\hline $\begin{array}{l}7 \text { Monetary \& Qua } \\
\text { ntitative }\end{array}$ & 1 & 5,00 & 1 & 10,00 & 0 & 0,00 & 0 & 0,00 & 0 & 0,00 \\
\hline $\begin{array}{l}8 \text { Descriptive, } \\
\text { Monetary \& Quan }\end{array}$ & 3 & 15,00 & 1 & 10,00 & 0 & 0,00 & 1 & 20,00 & 1 & 50,00 \\
\hline TOTAL & 20 & $(20)$ & 10 & $(10)$ & 3 & (3) & 5 & (5) & 2 & (2) \\
\hline
\end{tabular}

Chi-squared with 21 degrees of freedom $=18,5641 \quad$ (p $=0,6131$ )

Rows: 3.2.1. DISCHRRgS Type of information

Columa: PA groups from analyais of type of enviromental information disclosed and Economic $\mathrm{DEA}$

\begin{tabular}{|c|c|c|c|c|c|c|c|c|c|c|}
\hline \multirow[b]{2}{*}{ 3.2.1. DISCHARGES } & \multicolumn{2}{|c|}{ TOTAL } & \multicolumn{2}{|c|}{ Group 1} & \multicolumn{2}{|c|}{ Group 2} & \multicolumn{2}{|c|}{ Group 3} & \multicolumn{2}{|c|}{ Group 4} \\
\hline & Frec & 8 & Frec & 8 & Frec & 8 & Frec & 8 & Frec & 8 \\
\hline 2 Descriptive & 2 & 10,00 & 0 & 0,00 & 2 & 66,67 & 0 & 0,00 & 0 & 0,00 \\
\hline $\begin{array}{l}5 \text { Descriptive } \\
\text { Monetary }\end{array}$ & 1 & 5,00 & 0 & 0,00 & 0 & 0,00 & 1 & 20,00 & 0 & 0,00 \\
\hline 6 Descriptive $\&$ & 13 & 65,00 & 8 & 80,00 & 1 & 33,33 & 3 & 60,00 & 1 & 50,00 \\
\hline $\begin{array}{l}7 \text { Monetary \& Qua } \\
\text { ntitative }\end{array}$ & 2 & 10,00 & 2 & 20,00 & 0 & 0,00 & 0 & 0,00 & 0 & 0,00 \\
\hline $\begin{array}{l}8 \text { Descriptive, } M \\
\text { onetary y Quan }\end{array}$ & 2 & 10,00 & 0 & 0,00 & 0 & 0,00 & 1 & 20,00 & 1 & 50,00 \\
\hline TOTAL & 20 & $(20)$ & 10 & (10) & 3 & (3) & 5 & (5) & 2 & (2) \\
\hline
\end{tabular}

Chi-squared with 21 degrees of freedom $=22,2308 \quad(p=0,3863$ ) 


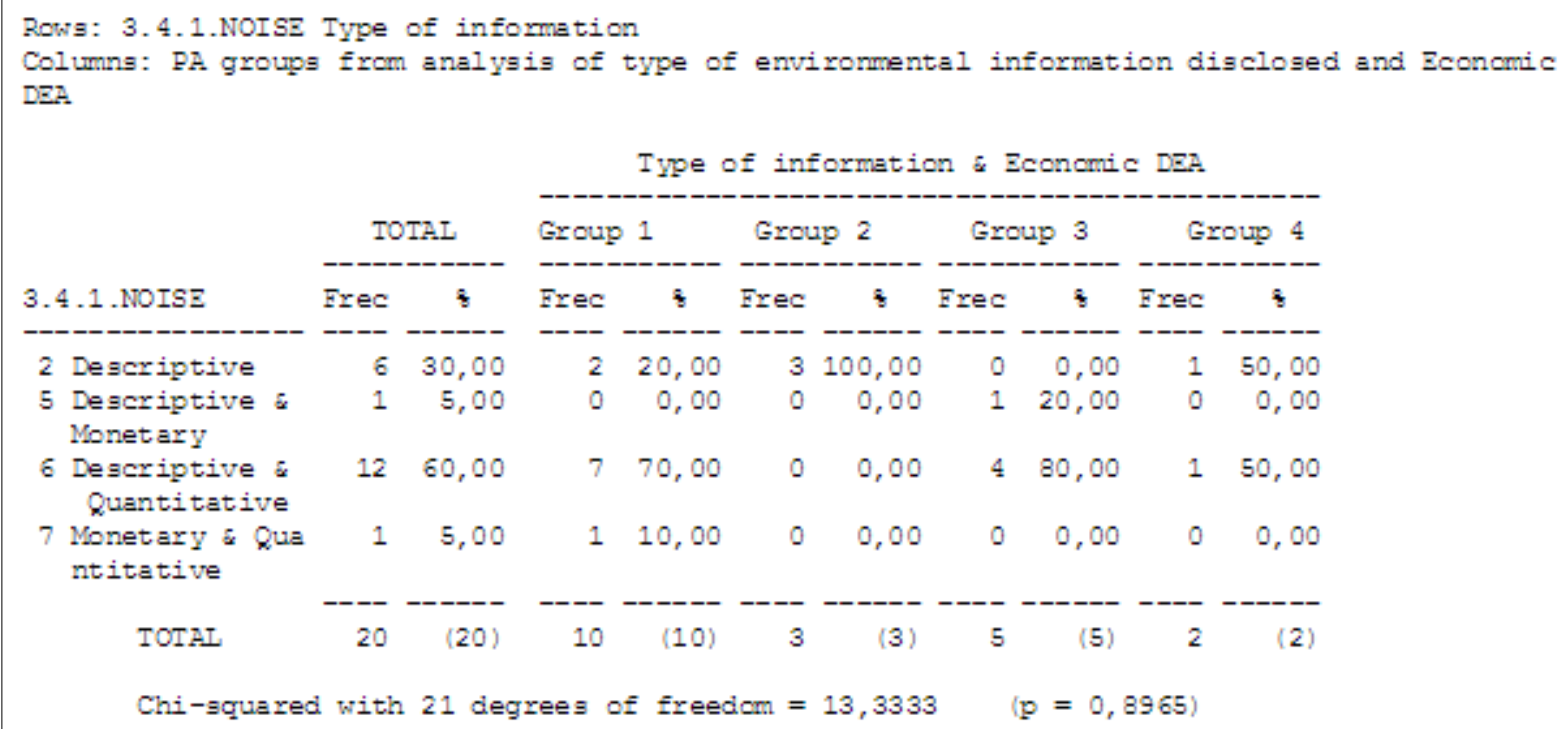

Table 12. Groups from analysis of type of environmental information disclosed

\subsubsection{PA groups from analysis of frequency of environmental information disclosed}

The second cluster analysis was to group PAs by years/periods of historic data provided in their environmental disclosures on consumption of natural resources and $\mathrm{CO}_{2}$ emissions.

The following variables were used.

- 2.1.2.2. ENERGY disclosure years/periods

- 2.2.3. WATER disclosure years/periods

- 2.2.3. $\mathrm{CO}_{2}$ EMISSIONS disclosure years/periods

- DEA Economic Efficiency Score

Table 13 shows the PA groups defined and the members of each group. 


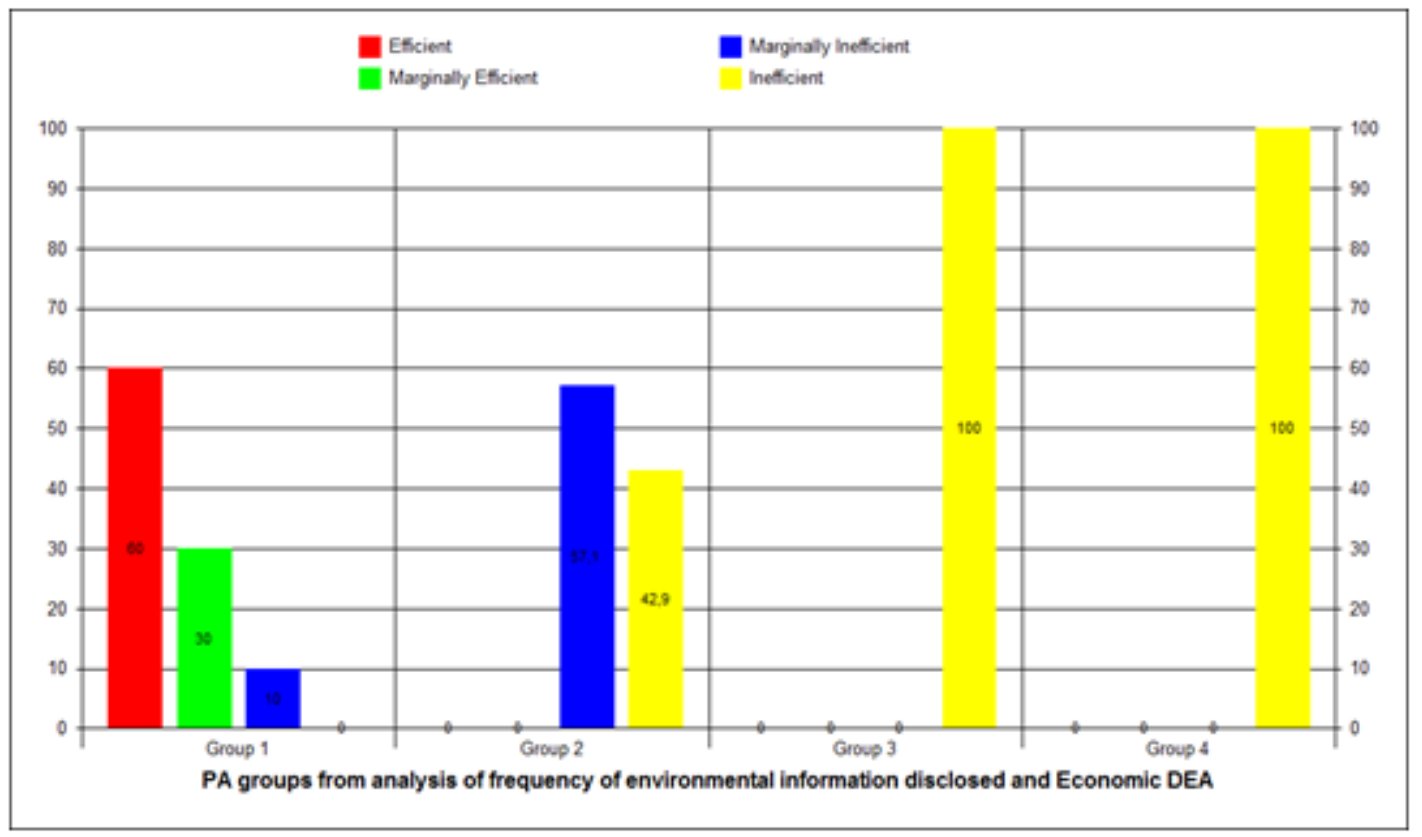

Figure 3. Distribution of efficiency by group

Figure 3 shows the distribution of efficiency by groups, as determined by cross-tabulating the previously defined efficiency categories and the groups obtained in this second cluster. In this analysis, group 1 once again includes the efficient PAs (Bahía de Algeciras, Barcelona, Cartagena, Ceuta, Motril and Valencia); the marginally efficient (A Coruña, Las Palmas and Balearic Islands), and one marginally inefficient PA (Gijón). Group 2 is comprised of the rest of the marginally inefficient PAs (Avilés, Ferrol-San Cibrao, Tarragona and Huelva), and of inefficient PAs having an efficiency score in their category above 74\% (Bilbao, Melilla and S. Cruz de Tenerife). Groups 3 and 4 contain the remaining inefficient PAs (Castellón, Vigo and Santander). 


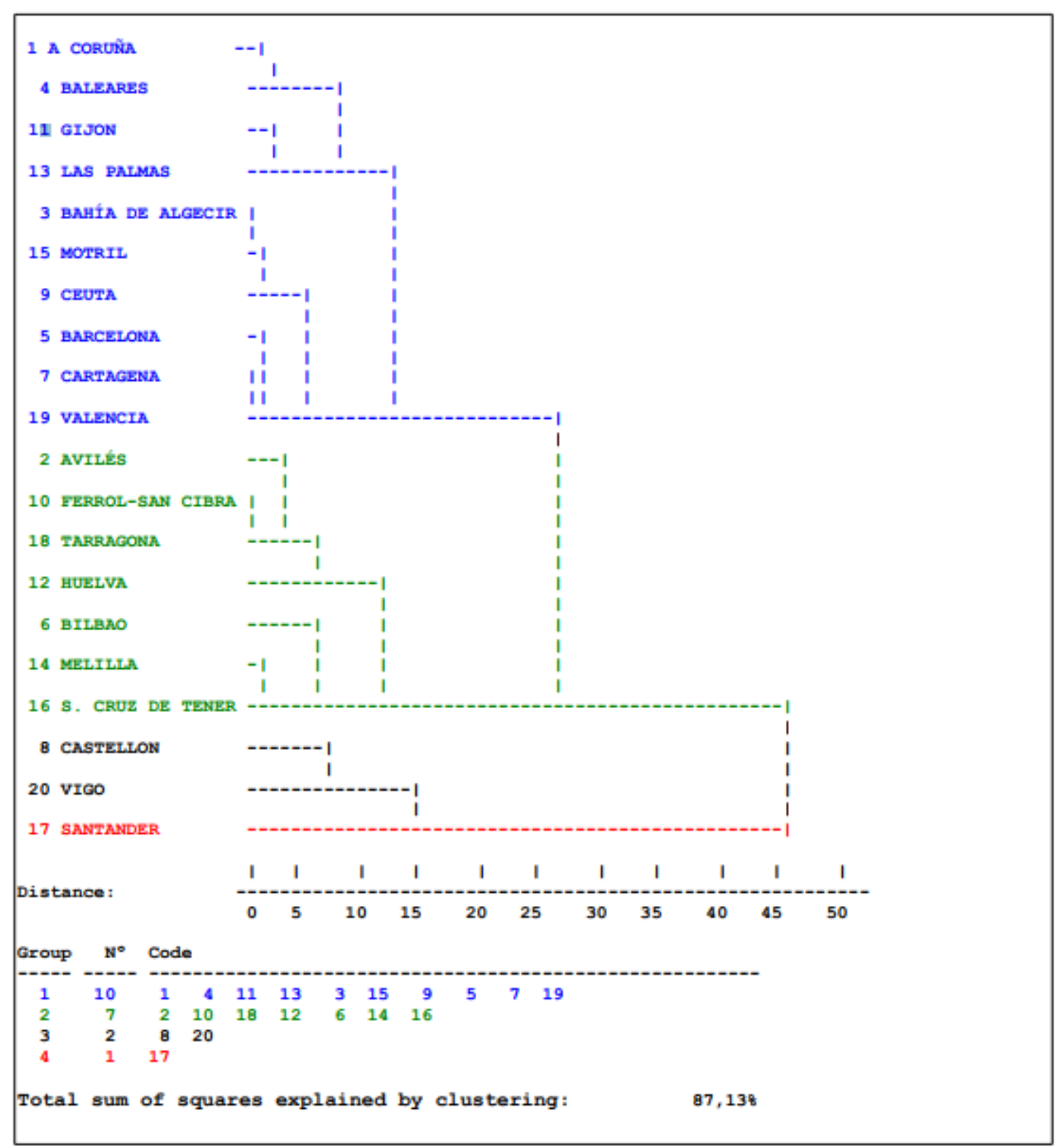

Table 13. Dendrogram- PAs groupsfrom analysis of frequency of environmental information disclosed

As seen in Table 14, groups 3 and 4, while those with the lowest efficiency ratings, reported the variables analyzed (energy, water and emissions) over the longest time-frames, annually or providing 3 years of historical data. A large proportion of the PAs included in groups 1 and 2 make no reference to specific time-frames in their disclosures on the three variables. 


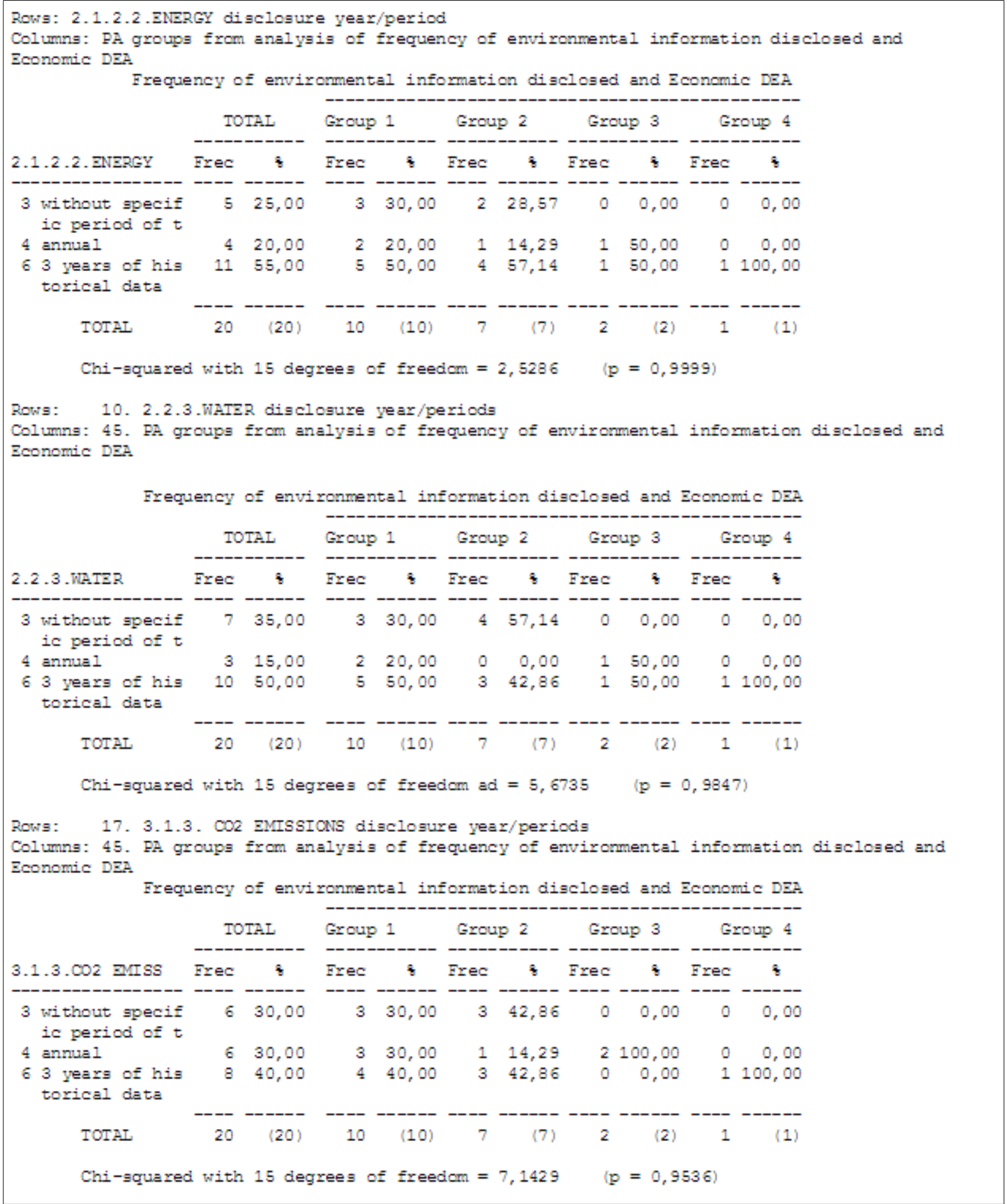

Table 14. Frequency of environmental information disclosed

\subsubsection{PA classification by environmental impact management}

The third cluster analysis was to classify PAs by the annual reduction targets each had cited for high environmental impact activities. The variables considered were the following: 
- 3.1.6.1. EMISSIONS REDUCTION annual targets

- 3.2.3. DISCHARGES annual targets

- 3.3.3. HAZARDOUS WASTE reduction targets

- 3.4.2. NOISE annual targets

- DEA Economic Efficiency Score

The dendogram (Table 15), shows the results of this cluster analysis.

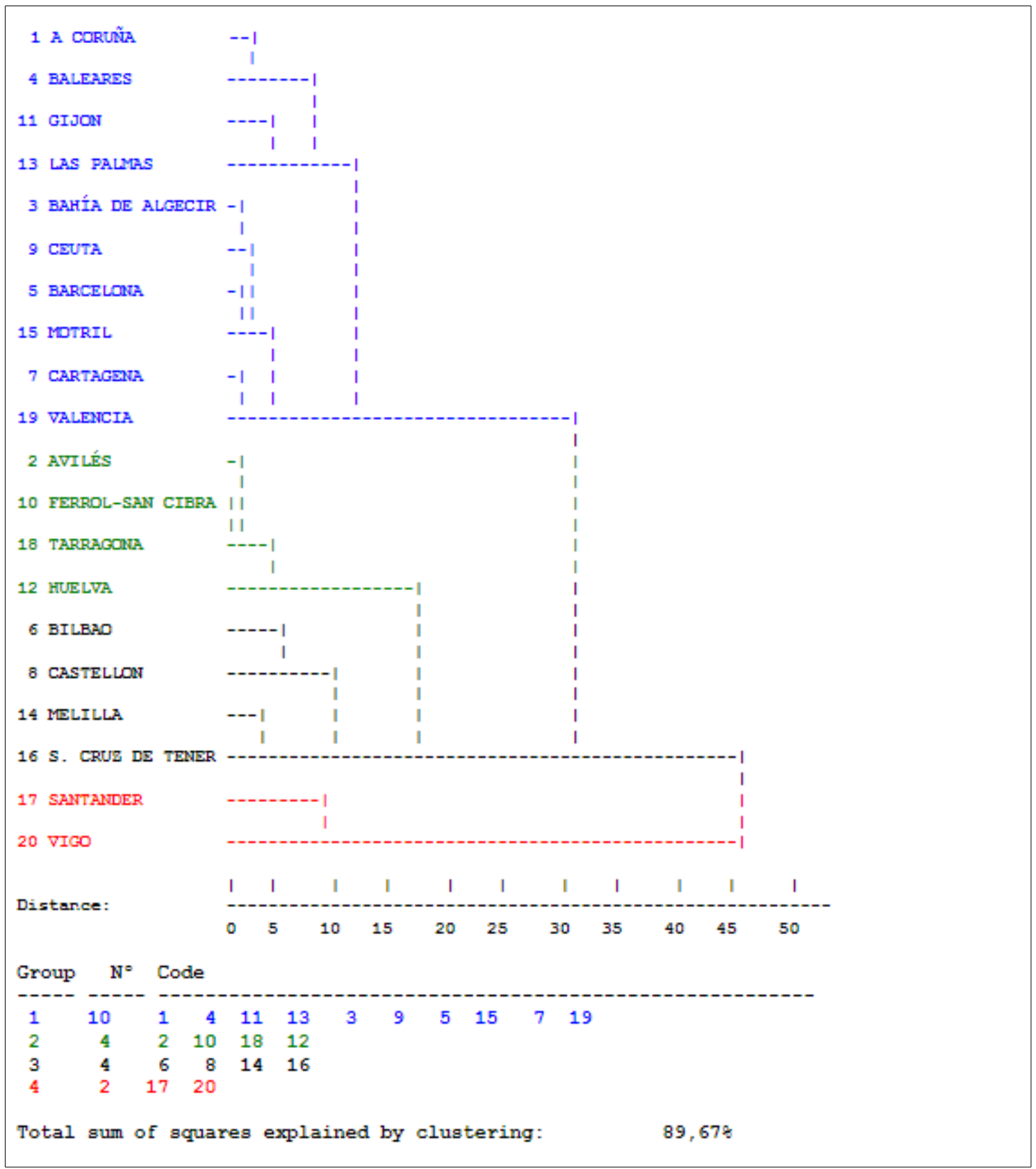

Table 15. Dendogram - PA classification by environmental impact management 
Figure 4 shows the efficiency distribution of each of the groups, obtained in the cluster analysis. As in the previous clusters, group 1 contains all of the efficient and marginally efficient PAs, and the one marginally inefficient PA, (Gijón) which is included due to highest efficiency score within its group. In group 2 are the remaining marginally inefficient PAs. Groups 3 and 4 are comprised of the inefficient PAs. Group 3: Bilbao, Castellón, Melilla and S. Cruz de Tenerife and group 4: Santander and Vigo.

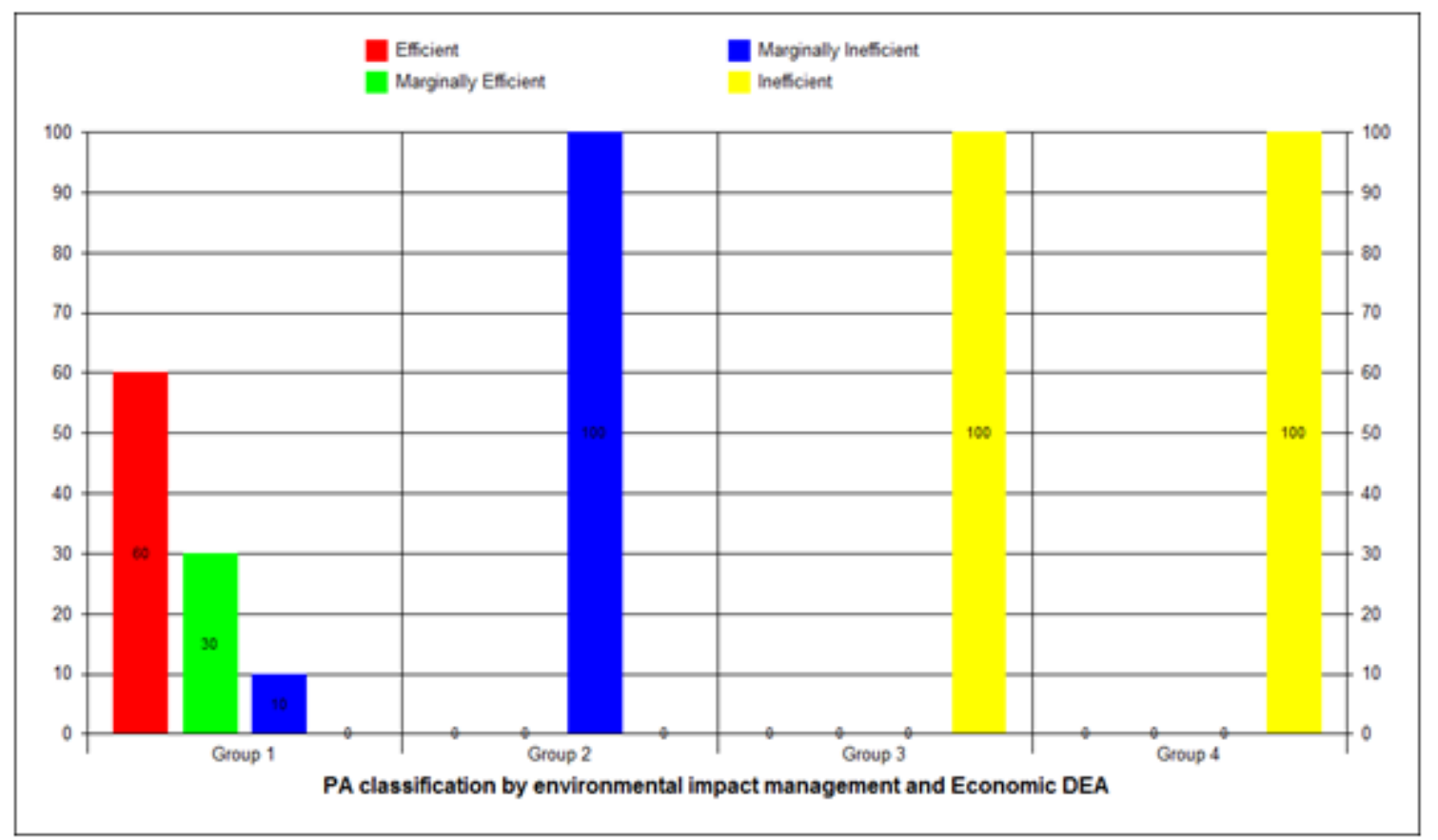

Figure 4. Distribution of efficiency by group

As reflected in Table 16, of group 1 PAs, 70\% have established reduction targets for emissions, discharges and hazardous waste. Remarkably, none $(0 \%)$ of group 2 PAs have set any emissions reduction target for the variables considered.

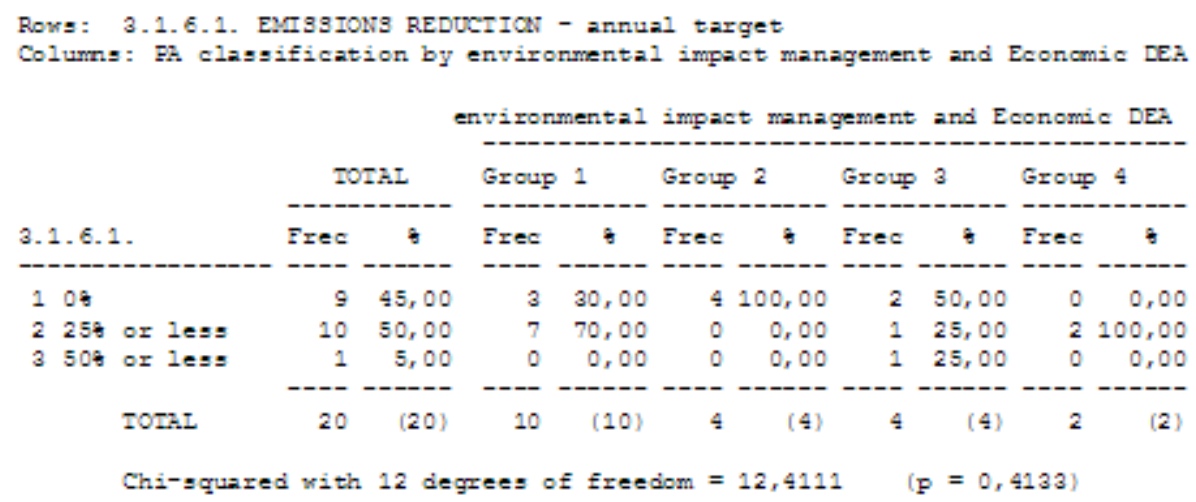




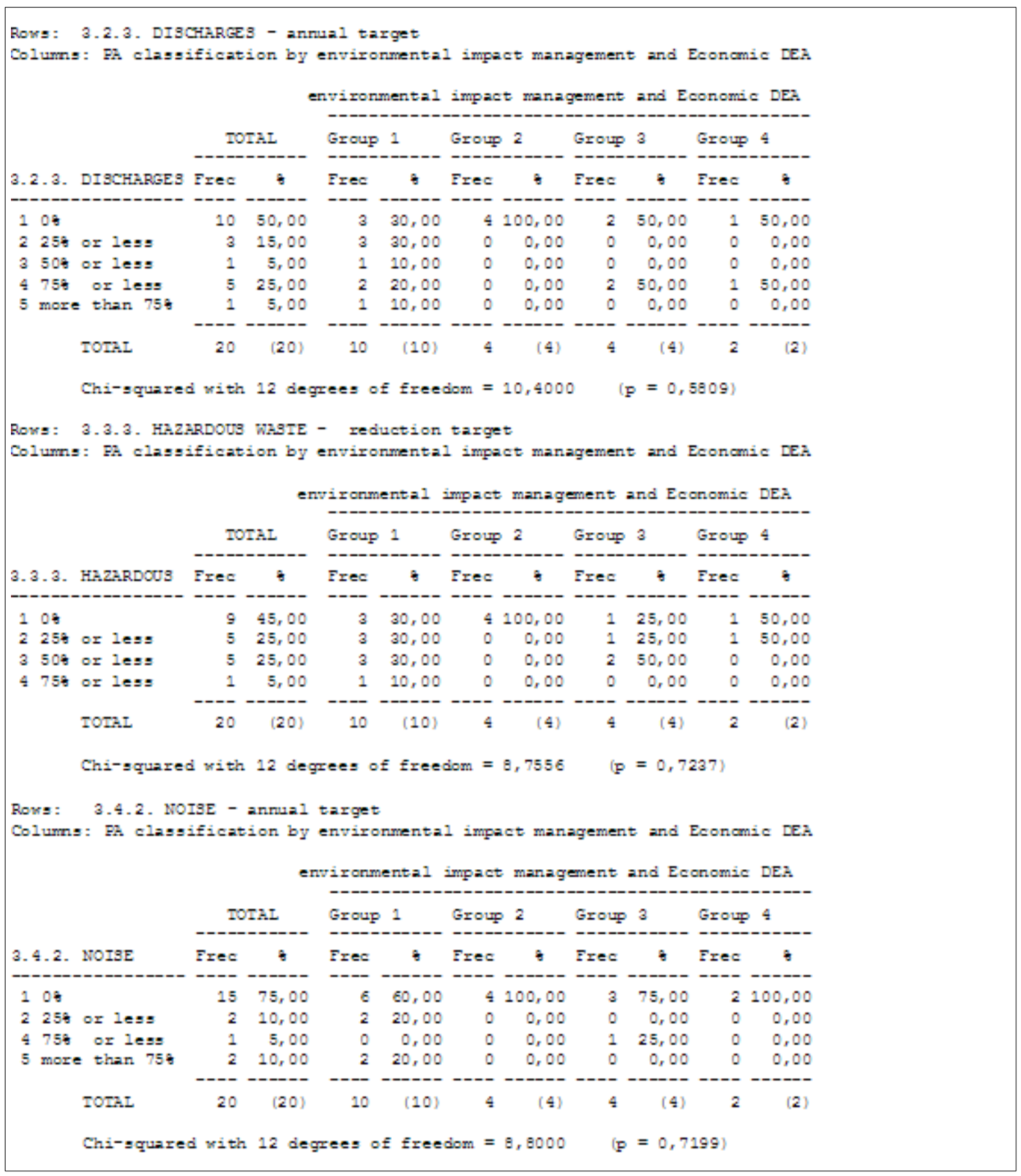

Table 16. Environmental impact management

Noise management is the variable most neglected by all 4 groups. Only 40\% of PAs within group 1 and $25 \%$ of group 3 have established noise reduction targets.

\subsubsection{PA classification by natural resources management}

The fourth and final cluster analysis (Table 17) was to classify PAs by management of the natural resources used. The variables used to build these groups were: 
- 2.1.3.2. ENERGY CONSUMPTION reduction due to energy efficiency measures ( $\%$ over previous reporting period)

- 2.2.5. WATER reused and recycled (\%)

- DEA Economic Efficiency Score

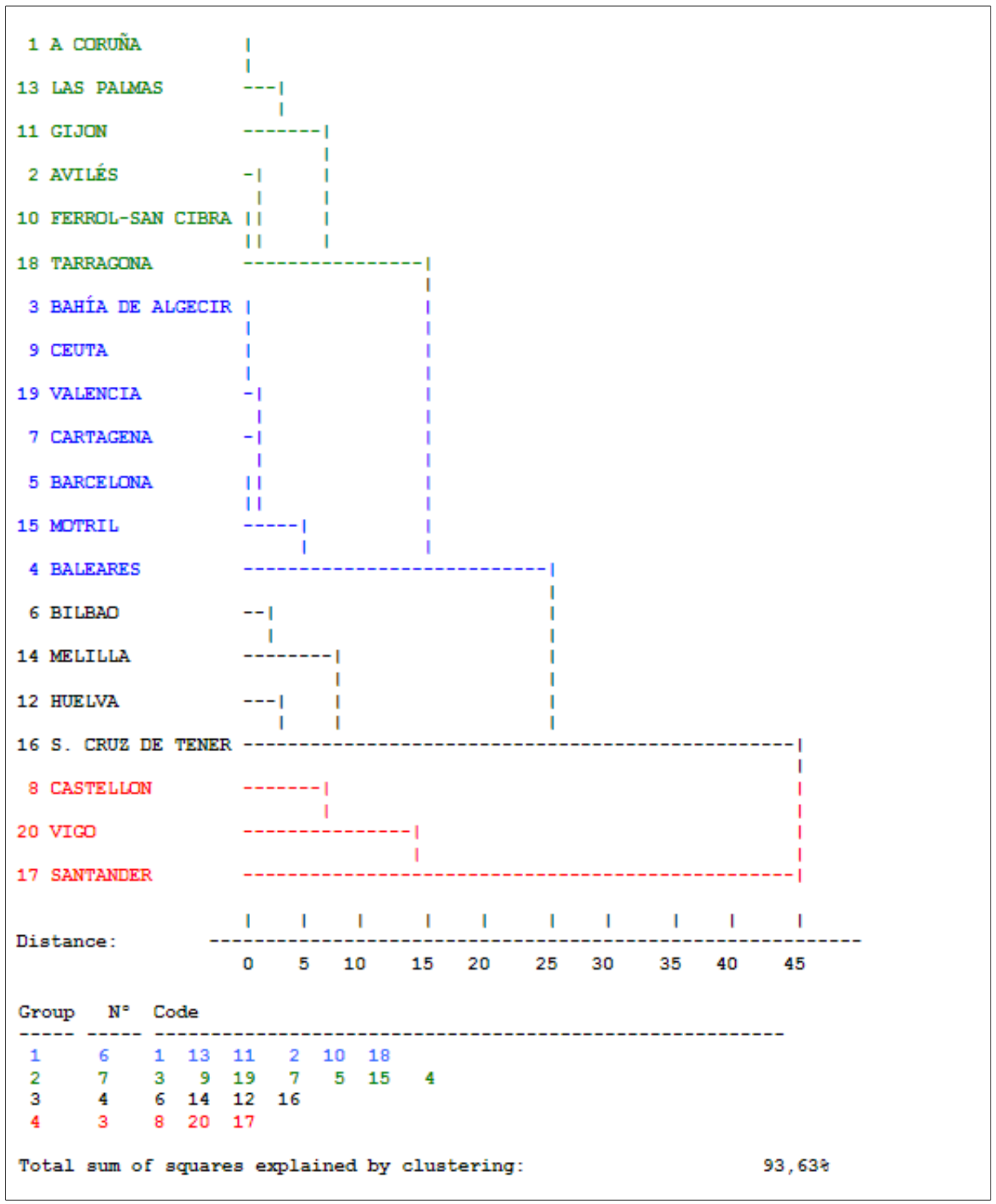

Table 17. Dendrogram - PA classification by natural resources management 
As shown in Figure 5, group 1 is comprised of PAs considered marginally efficient (A Coruña and Las Palmas) and marginally inefficient (Avilés, Ferrol-San Cibrao, Gijón and Tarragona). Group 2 is comprised of efficient PAs (Bahía de Algeciras, Barcelona, Cartagena, Ceuta, Motril and Valencia) and includes one marginally efficient PA (Balearic Islands) due to highest efficiency score in its category (94,83\%). Group 3 is comprised of marginally inefficient PAs with lowest efficiency scores (Bilbao, Melilla, Huelva and S Cruz de Tenerife). Group 4 is comprised of the most inefficient PAs (Castellón, Vigo and Santander).

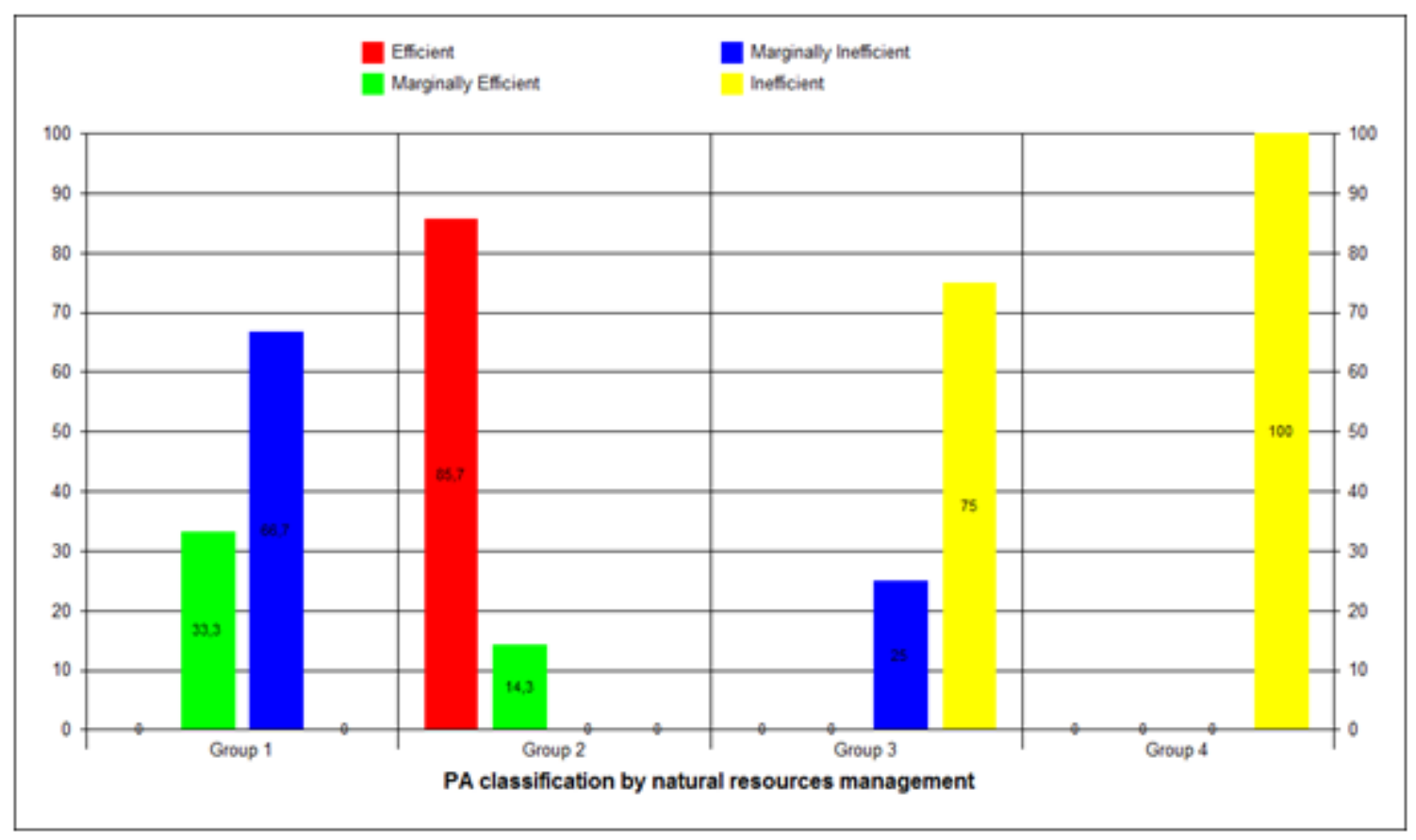

Figure 5. Distribution of efficiency by group 


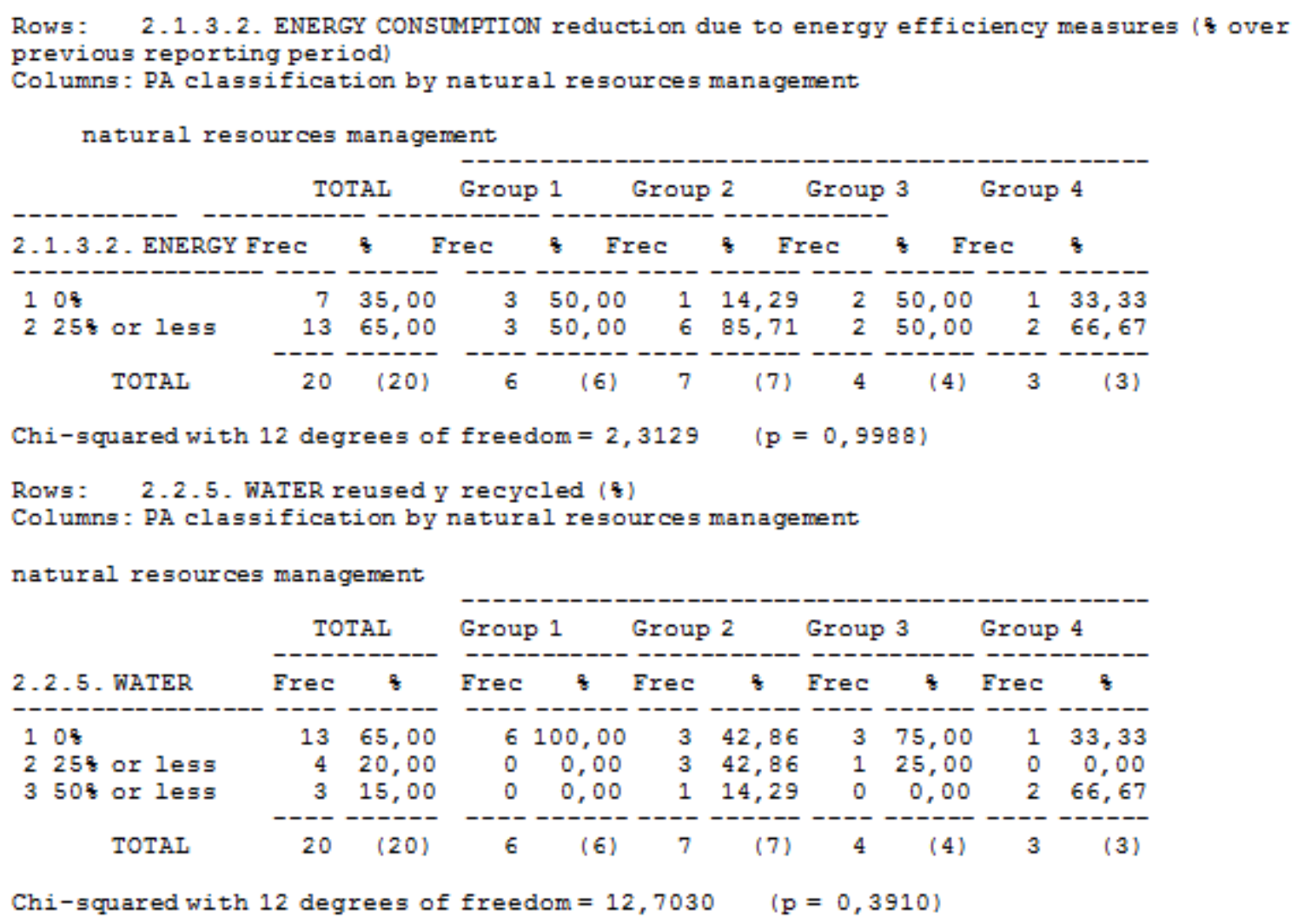

Table 18. Energy and water management

Table 18 reflects the $\%$ of PAs that, due to environmental management practices, have achieved improvements in their consumption of energy, and of reused/recycled water. Of these, group 2 (among the most efficient) contains the greatest percentage of PAs (85\%) to achieve energy efficiency related reductions of up to $25 \%$, and also reports the highest percentage of water reuse and recycling. The results of Group 4, the least efficient PAs, deserves mention here. Of these, $66 \%$ report energy efficiency improvements of up to $25 \%$, and reused/recycled water improvements of up to $50 \%$.Improvement percentages are lower for the PAs in groups 1 and 2, with 50\% reporting improved energy consumption and $0 \%-25 \%$ reporting improvements in water reuse/recycling, respectively. 


\section{Conclusions and future lines of research}

$73.34 \%$ of efficient PAs report on five or more environmental management aspects in their environmental disclosures, a figure that rises to $100 \%$ for marginally efficient PAs, and moves to $80 \%$ and $83.33 \%$, for the marginally inefficient and the inefficient PAs, respectively (see Table 19).

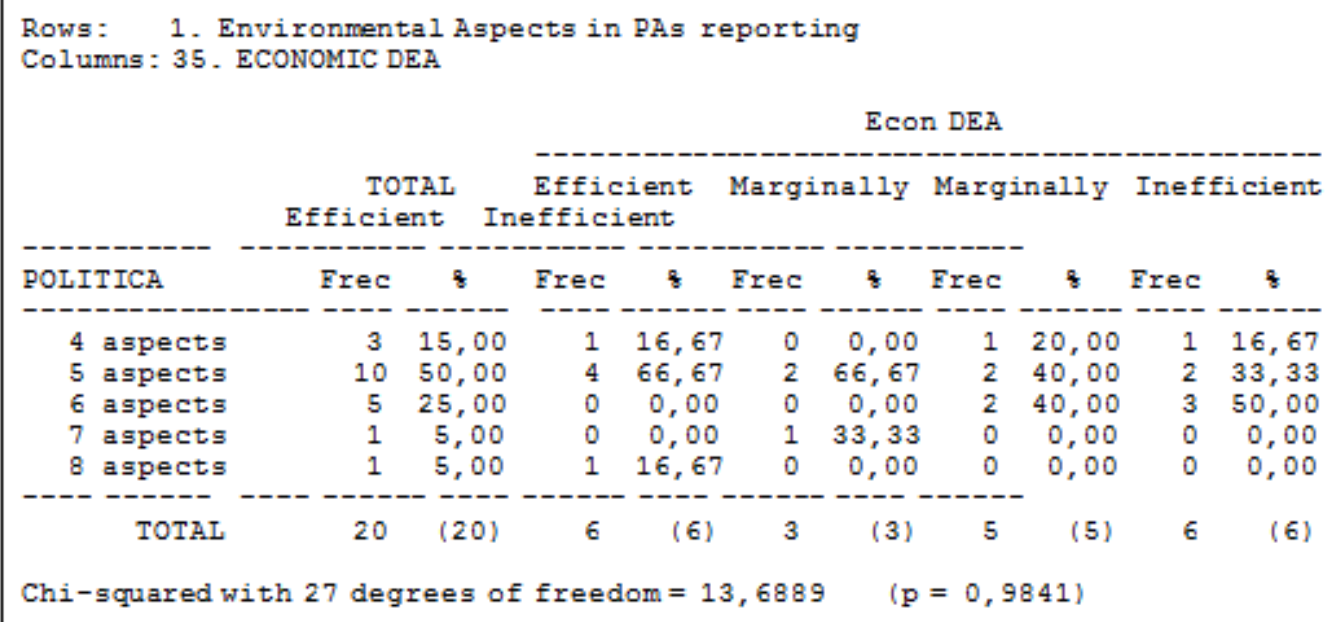

Table 19. Economic efficiency and environmental management

However, in three of the four cluster analyses, all efficient and marginally efficient PAs are grouped together, which means the environmental reporting of these PAs was similar in terms of type and frequency/periods for data supplied on emissions, discharges, hazardous waste and noise. The inefficient and the marginally inefficient PAs with relatively lower efficiency scores, are also grouped together.

Tables 20 and 20b summarize the results of the four cluster analyses that enable us to characterize the PAs by environmental efficiency cross-referenced with their environmental management disclosures. Efficient and marginally efficient PAs are those providing the highest level of detail regarding the management of water, discharges and noise; $70 \%$ of the PAs in these groups also provide annual information on energy, water, $\mathrm{CO}_{2}$ emissions and set reduction targets for discharges, hazardous waste and emissions. These are also the only PAs that establish noise reduction targets. 


\begin{tabular}{|l|l|l|}
\hline \multicolumn{1}{|c|}{ Efficient and marginally efficient } & \multicolumn{1}{|c|}{ Marginally inefficient } & \multicolumn{1}{c|}{$\begin{array}{l}\text { Inefficient and marginally } \\
\text { inefficient (lowest scores) }\end{array}$} \\
\hline \multicolumn{3}{|c|}{ Cluster analysis: Information type } \\
\hline WATER & $\begin{array}{l}33 \% \text { provide descriptive and } \\
\text { quantitative } \\
\text { descriptive/quantitative data, and 10\% of PAs provide } \\
\text { also provide economic. }\end{array}$ & $\begin{array}{l}50 \%-60 \% \text { of PAs (depends on group) } \\
\text { provide descriptive/quantitative data } \\
\text { and } 2 \text { also provide economic. }\end{array}$ \\
\hline $\begin{array}{l}\text { DISCHARGES } \\
\text { 80\% of PAs provide } \\
\text { descriptive/quantitative data, and } 10 \% \\
\text { also provide economic. }\end{array}$ & $\begin{array}{l}33 \% \text { provide descriptive and } \\
\text { quantitative }\end{array}$ & $\begin{array}{l}50 \%-60 \% \text { of PAs provide } \\
\text { descriptive/quantitative data and } 2 \text { also } \\
\text { provide economic. }\end{array}$ \\
\hline $\begin{array}{l}\text { NOISE } \\
\text { 70\% provide descriptive and } \\
\text { quantitative. }\end{array}$ & $100 \%$ provide only descriptive. & $\begin{array}{l}50 \%-80 \% \text { provide descriptive and } \\
\text { quantitative. }\end{array}$ \\
\hline
\end{tabular}

Table 20. Summary of results by efficiency category

\begin{tabular}{|c|c|c|}
\hline \multicolumn{3}{|c|}{ Cluster analysis: frequency and historic } \\
\hline \multicolumn{3}{|l|}{ ENERGY } \\
\hline $\begin{array}{l}70 \% \text { provide annual or historic up to } 3 \\
\text { yrs. }\end{array}$ & $\begin{array}{l}71 \% \text { provide annual or historic up to } 3 \\
\text { yrs. }\end{array}$ & $\begin{array}{l}100 \% \text { provide annual or historic up to } 3 \\
\text { yrs. }\end{array}$ \\
\hline \multicolumn{3}{|l|}{ WATER } \\
\hline $\begin{array}{l}70 \% \text { provide annual or historic up to } 3 \\
\text { yrs. }\end{array}$ & $\begin{array}{l}42 \% \text { provide annual or historic up to } 3 \\
\text { yrs. }\end{array}$ & $\begin{array}{l}100 \% \text { provide annual or historic up to } 3 \\
\text { yrs. }\end{array}$ \\
\hline \multicolumn{3}{|l|}{$\mathrm{CO}_{2}$ EMISSIONS } \\
\hline $\begin{array}{l}70 \% \text { provide annual or historic up to } 3 \\
\text { yrs. }\end{array}$ & $42 \%$ provide historic up to $3 \mathrm{yrs}$. & $\begin{array}{l}100 \% \text { provide annual or historic up to } 3 \\
\text { yrs. }\end{array}$ \\
\hline \multicolumn{3}{|c|}{ Cluster analysis: environmental impact management } \\
\hline \multicolumn{3}{|l|}{ CO2 EMISSIONS } \\
\hline $70 \%$ set emissions reduction targets. & $\begin{array}{l}\text { None reports emissions reduction } \\
\text { targets }\end{array}$ & $\begin{array}{l}50 \%-100 \% \text { set emissions reduction } \\
\text { targets }\end{array}$ \\
\hline \multicolumn{3}{|l|}{ DISCHARGES } \\
\hline $70 \%$ include emission reduction targets & None set emissions reduction targets & $50 \%$ set emissions reduction targets \\
\hline \multicolumn{3}{|l|}{ HAZARDOUS WASTE } \\
\hline $\begin{array}{l}70 \% \text { set hazardous waste reduction } \\
\text { targets }\end{array}$ & $\begin{array}{l}\text { None set hazardous waste reduction } \\
\text { targets }\end{array}$ & $\begin{array}{l}50 \%-70 \% \text { set hazardous waste } \\
\text { reduction targets. }\end{array}$ \\
\hline \multicolumn{3}{|l|}{ NOISE } \\
\hline $\begin{array}{l}40 \% \text { set noise emissions reduction } \\
\text { targets }\end{array}$ & $\begin{array}{l}\text { None reports any noise emissions } \\
\text { reduction targets }\end{array}$ & $\begin{array}{l}\text { Inefficient PAs do not establishnoise } \\
\text { emissions reduction targets }\end{array}$ \\
\hline
\end{tabular}

Table 20b. Summary of results by efficiency category

Efficient PAs also stand out for their water and energy management. 85\% reported reductions in energy consumption of up to $25 \%$, and $57 \%$ also report the percentages of water recycled and reused.

Within the study, the environmental disclosure practices of the marginally inefficient PAs were poorest: none set environmental impact management targets for any of the 4 items, $\mathrm{CO}_{2}$ emissions, discharges, hazardous waste or noise. They provide solely descriptive information, which fits with the data that only $33 \%$ of the PAs of this category provided descriptive and quantitative information on water and discharge management. 
Regarding water and energy management, the marginally efficient and the marginally inefficient PAs have similar environmental reporting behaviours: $50 \%$ of these report reduced energy consumption, but do not report percentages of water recycled or reused.

Here it should be noted that the inefficient and marginally inefficient PAs (with lowest scores in their category) consistently provide higher levels of detail in their disclosures than, at least, $50 \%$ of the PAs. They usually provide descriptive and quantitative data, and set targets for emissions, discharges and hazardous waste. $100 \%$ provide annual information and/or up to 3 years historic. Regarding energy and water management, $50 \%-66 \%$ of the inefficient PAs report energy consumption reductions of up to $25 \%$.Further, between $25 \%$ and $66 \%$ of the PAs report the percentages of recycled and reused water.

General observations: the most economically efficient PAs are those that provide the fullest environmental disclosure data on the four environmental reporting indicators considered: type, frequency, environmental impact, and water and energy management, as was concluded by Al-Tuwaijri et al. (2004). The results of the study show that the most economically efficient PAs do a better job of managing the environmental impact of their energy and water use.

The results of this study of Spanish Port Authorities echo the findings of a study done of 10 major U.S. ports (Cheon, Maltz \& Dooley, 2017), which found that economic performance is linked to good environmental management and practices, and good environmental management has become a competitive advantage for ports. The U.S. and Spain have both amended existing port legislation to include requirements on the environmental sustainability of port operations, while not losing sight of the economic fact that ports are businesses.

Spanish law 33/2010 will most assuredly be followed by further environmental regulations and requirements for ports. We feel that the Spanish Ports Authorities should consider adopting Integrated Reporting Models in anticipation of events. This would enable Spanish ports to gradually improve their environmental reporting on financials, economic resources dedicated and governance, while also serving to inform stakeholders of their environmental performance, resource consumption, plans, targets and risk/opportunity strategies. As noted by Castilla and Roselló (2013).

In our opinion, future research could include a longitudinal study of several years to discern how the environmental disclosure and economic efficiency of Spanish ports authorities has evolved.

In this respect, in further study it would be pertinent to conduct an environmental performance and Eco-efficiency analysis (Burnett \& Hansen, 2008; Haralambides \& Gujar, 2012), applying a DEA model constructed from the environmental information reported by the PAs. 


\section{References}

Al-Tuwaijri, S., Christensen, T.E., \& Hughes, KE, II. (2004). The relations among environmental disclosure, environmental performance, and economic performance: A simultaneous equations approach. Accounting, Organizations and Society, 29(5), 447-471. Available online at: https://search.proquest.com/docview/195121620?accountid=14475 https://doi.org/10.1016/S0361-3682(03)00032-1

Bahauddin, K.M. (2014). Environmental system management and governance needs in a developing country. Environment Systems \& Decisions, 34(2), 342-357. https://doi.org/10.1007/s10669-013-9472-3

Berthelot, S., Cormier, D., \& Magnan, M. (2003). Environmental disclosure research: Review and synthesis. Journal of Accounting Literature, 22, 1-44. Available online at: http://search.proquest.com/docview/216305124?accountid=14475

Burnett, R.D., \& Hansen, D.R. (2008). Ecoefficiency: Defining a role for environmental cost management. Accounting, Organizations and Society, 33(6), 551. Available online at: http://search.proquest.com/docview/195146437?accountid=14475 https://doi.org/10.1016/j.aos.2007.06.002

Burritt, R.L. (2012). Environmental performance accountability: Planet, people, profits. Accounting, Auditing \& Accountability Journal, 25(2), 370-405. https://doi.org/10.1108/09513571211198791

Castilla, M.L., \& de Rosselló, M. (2013). Avances en España. hacia el reporting integrado/Spain advances. towards integrated reporting. Boletín De Estudios Económicos, 68(208), 61-87. Available online at: https://search.proquest.com/docview/1364797277? accountid=14475

Cerreta, M., \& Toro, P. de (2012). Strategic environmental assessment of port plans in Italy: Experiences, approaches, tools. Sustainability, 4(11), 2888-2921. https://doi.org/10.3390/su4112888

Cheon, S., Maltz A., \& Dooley, K. (2017). The link between economic and environmental performance of the top 10 U.S. Ports, Maritime Policy \& Management, 44(2), 227-247.

https://doi.org/10.1080/03088839.2016.1275860

da Rosa, F.S., Lunkes, R.J., Pfitscher, E.D., Feliu, V.R., \& Soler, C.C. (2012). Contabilidad medioambiental en España: Proceso estructurado de revisión y análisis teórico referencial/Environmental accounting in Spain: Structured review process and theoretical analysis. Contabilidad y Negocios, 7(14), 23-48. Available online at: http://search.proquest.com/docview/1318935596? $\underline{\text { accountid }=14475}$ 
Ferrón-Vílchez, V., de la Torre Ruiz, J.M., \& Aragón Correa, J.A. (2010). Calidad y algo más: El efecto conjunto de la gestión de la calidad y mediombiental en la rentabilidad de la empresa (Quality and something else: The joint effect of the quality and environmen tmanagement in business profitability). Revista Española De Financiación y Contabilidad, 39(148), 655-675. Available online at: https://search.proquest.com/docview/921238661? accountid=14475 https://doi.org/10.1080/02102412.2010.10779693

Giner. A., da Rosa, F.S., Lunkes, R.J., Ripoll, V.M., \& Crespo, C. (2012). Sustentabilidade ambiental: Um estudo na autoridade portuária de Valencia, Espanha. Revista De Gestão, Finanças e Contabilidade, 2(1), 2-20. Available online at: http://search.proquest.com/docview/1692031917?accountid=14475 https://doi.org/10.18028/2238-5320/rgfc.v2n1p2-20

Haralambides, H., \& Gujar, G. (2012). On balancing supply chain efficiency and environmental impacts: An eco-DEA model applied to the dry port sector of india. Maritime Economics \& Logistics, 14(1), 122-137. https://doi.org/10.1057/mel.2011.19

Horgn-Jinh, C., \& Ling-Chu, L. (2012). Using the data envelopment analysis (DEA) model to evaluate the operational efficiency. African Journal of Business Management, 6(37), 10143-10158. https://doi.org/10.5897/AJBM11.2150

Hou, L., \& Gerrlings, H. (2016). Dynamics in sustainable port and hinterland operations: A conceptual framework and simulation of sustainability measures and their effectiveness, based on an application to the Port of Shanghai. Journal of Cleaner Production, 135(2016), 449e456.

https://doi.org/10.1016/j.jclepro.2016.06.134

KMPG (2015). Survey of Corporate Responsibility Reporting. Available online at: http://www.kpmg.com/cn/en/issuesandinsights/articlespublications/pages/kpmg-survey-of-corporate-responsibilityreporting-2015-o-201511.aspx

Kolk, A., \& Veen, M.V.D. (2002). Dilemmas of Balancing Organizational and Public Interests: How Environment Affects Strategy in Dutch Main Ports. European Management Journal, 20(1), 45-54. https://doi.org/10.1016/S0263-2373(01)00113-X

Luttenberger, A., PhD. (2010). Achieving the quality of services in sea ports through regulations. Faculty of Tourism and Hospitality Management in Opatija. Biennial International Congress. Tourism \& Hospitality Industry, 1034-1040. Available online at: http://search.proquest.com/docview/763422317? accountid $=14475$

Molina-Azorín, J.F., Claver-Cortés, E., López-Gamero, M.D., \& Tarí, J.J. (2009). Green management and financial performance: A literature review. Management Decision, 47(7), 1080-1100. https://doi.org/10.1108/00251740910978313 
Navarro, C.L., \& Zamora, A.I. (2014). Economic Efficiency of the International Port System. Intenational Business Research, 7(11), 108-116. https://doi.org/10.5539/ibr.v7n11p108

Negash, M. (2012). IFRS and environmental accounting. Management Research Review, 35(7), 577-601. https://doi.org/10.1108/01409171211238811

OECD environmental performance reviews: Spain 2015. (2015). Paris: Organisation for Economic Cooperation and Development (OECD). Available online at: http://search.proquest.com/docview/1662483593? accountid $=14475$

Poltrack, S. (2000). The Maritime Industry and Our Environment: The Delicate Balance of Economic and Environmental Concerns, Globally, Nationally, and Within the Port of Baltimore. [Versión electrónica], Hein Online, 51-78.

Puertos del Estado (2012). Memoria de Sostenibilidad- Sistema portuario de Interés general.

Santesmases Mestre, M. (2005). Diseño y análisis de encuestas en investigación social. Madrid: Ed. Pirámide

SchØyen, H., \& Odeck, J. (2013). The technical efficiency of Norwegian container ports: A comparison to some Nordic and UK container ports using Data Envelopment Analysis. Maritime Economics \& Logistics, 15(2), 197-221. https://doi.org/10.1057/mel.2013.3

Stojanovic, T.A., Smith, H.D.O., \& Wooldridge, C.F. (2006). The impact of the habitats directive on european port operations and management. GeoJournal, 65(3), 165-176. https://doi.org/10.1007/s10708006-0004-2

Synnot, R. (2013). Environmental imperatives for Australian ports. Australian Journal of Maritime and Ocean Affairs, 5(4), 133-136. Available online at: http://search.proquest.com/docview/1470806183? accountid=14475 https: / / doi.org/10.1080/18366503.2013.10815745

Tanc, A., \& Gokoglan, K. (2015). The impact of environmental accounting on strategic management accounting: A research on manufacturing companies. International Journal of Economics and Financial Issues, 5(2), 566-573. Available online at: http://search.proquest.com/docview/1678821776?accountid=14475

U.S. Environmental Protection Agency (EPA) Office of Policy, Economics, and Innovation Sector Strategies Division (2007). An Environmental Management System Primer for Ports: Advancing Port Sustainability. April.

Yang, C. (2013). A dea-based approach for evaluating the opportunity cost of environmental regulations. Asia - Pacific Journal of Operational Research, 30(2), A1-A17. Available online at: http://search.proquest.com/docview/1365231015?accountid=14475 https://doi.org/10.1142/S0217595912500492 
Whitlam, N. (2013). Ports and the environment 2013. Australian Journal of Maritime and Ocean Affairs, 5(4), 130-132. Available online at: http://search.proquest.com/docview/1470806199?accountid=14475 https://doi.org/10.1080/18366503.2013.10815744

Wong, C.W.Y. (2013). Leveraging environmental information integration to enable environmental management capability and performance. Journal of Supply Chain Management, 49(2), 114-136. Available online at: http://search.proquest.com/docview/1467437036?accountid=14475 https://doi.org/10.1111/jscm.12005

Intangible Capital, 2017 (www.intangiblecapital.org)

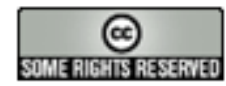

Article's contents are provided on an Attribution-Non Commercial 3.0 Creative commons license. Readers are allowed to copy, distribute and communicate article's contents, provided the author's and Intangible Capital's names are included. It must not be used for commercial purposes. To see the complete license contents, please visit http://creativecommons.org/licenses/by-nc/3.0/. 